University of Nebraska - Lincoln

DigitalCommons@University of Nebraska - Lincoln

Publications from USDA-ARS / UNL Faculty

U.S. Department of Agriculture: Agricultural

Research Service, Lincoln, Nebraska

$11-15-2019$

\title{
Comparison of Unused Water and Year-Old Used Water for Production of Channel Catfish in the Biofloc Technology System
}

\author{
Bartholomew W. Green \\ USDA, Agricultural Research Service, bart.green@usda.gov \\ Kevin K. Schrader \\ USDA, Agricultural Research Service, kevin.schrader@usda.gov \\ Steven D. Rawles \\ USDA, Agricultural Research Service, steven.rawles@usda.gov \\ Carl D. Webster \\ USDA, Agricultural Research Service, carl.webster@usda.gov \\ Matthew E. McEntire \\ USDA, Agricultural Research Service, matthew.mcentire@usda.gov
}

Follow this and additional works at: https://digitalcommons.unl.edu/usdaarsfacpub

Part of the Agriculture Commons, and the Aquaculture and Fisheries Commons

Green, Bartholomew W.; Schrader, Kevin K.; Rawles, Steven D.; Webster, Carl D.; and McEntire, Matthew E., "Comparison of Unused Water and Year-Old Used Water for Production of Channel Catfish in the Biofloc Technology System" (2019). Publications from USDA-ARS / UNL Faculty. 2416.

https://digitalcommons.unl.edu/usdaarsfacpub/2416

This Article is brought to you for free and open access by the U.S. Department of Agriculture: Agricultural Research Service, Lincoln, Nebraska at DigitalCommons@University of Nebraska - Lincoln. It has been accepted for inclusion in Publications from USDA-ARS / UNL Faculty by an authorized administrator of DigitalCommons@University of Nebraska - Lincoln. 


\title{
Comparison of unused water and year-old used water for production of channel catfish in the biofloc technology system
}

\author{
Bartholomew W. Green ${ }^{\mathrm{a}, *}$, Kevin K. Schrader ${ }^{\mathrm{b}}$, Steven D. Rawles ${ }^{\mathrm{a}}$, Carl D. Webster ${ }^{\mathrm{a}}$, \\ Matthew E. McEntire ${ }^{\mathrm{a}}$ \\ ${ }^{a}$ United States Department of Agriculture (USDA), Agricultural Research Service (ARS), Harry K. Dupree Stuttgart National Aquaculture Research Center (HKDSNARC), \\ P.O. Box 1050, Stuttgart, AR 72160-1050, USA \\ ${ }^{\mathrm{b}}$ United States Department of Agriculture, Agricultural Research Service, Natural Products Utilization Research Unit, National Center for Natural Products Research, Post \\ Office Box 1848, University, MS 38677-8048, USA
}

\section{A R T I C L E I N F O}

\section{Keywords:}

Channel catfish

Biofloc technology production system

Water quality

Macro- and trace-minerals

2-methylisoborneol and geosmin off-flavors

Phytoplankton

\begin{abstract}
A B S T R A C T
Since excreted feed nitrogen is bio-transformed efficiently in a fully functional mixotrophic biofloc technology production system, re-using this biofloc water over multiple production cycles should be beneficial. The present study, conducted in an outdoor biofloc technology production system, evaluated impacts on fish production characteristics and mineral status, common microbial off-flavors, and water quality dynamics for channel catfish (Ictalurus punctatus) reared in one-year-old waters with low or high total suspended solids used previously for two consecutive catfish biofloc studies or in unused (new) water. Total suspended solids were maintained at 300 to $400 \mathrm{mg} / \mathrm{L}$ in the unused and low total suspended solids used water treatments and allowed to accumulate in the high total suspended solids used water treatment. Tanks $\left(18.6 \mathrm{~m}^{2}, 15.7 \mathrm{~m}^{3}\right)$ were stocked with fingerlings $(47.5 \pm 0.8 \mathrm{~g} / \mathrm{fish})$ at $13.5 \mathrm{fish} / \mathrm{m}^{2}\left(16 \mathrm{fish} / \mathrm{m}^{3}\right)$ and grown for 181 days. Channel catfish production characteristics did not differ significantly among treatments. Overall, gross fish yield averaged $10.2 \mathrm{~kg} / \mathrm{m}^{3}$ and fish averaged $642 \mathrm{~g} /$ fish. Nitrate accumulation rate was affected by total suspended solids concentration with a significant reduction observed at the highest discharge of solids from the system, suggesting wash-out of nitrifiers. Treatment effects on water quality dynamics, macro- and trace-mineral status of water, feed, and fish, 2methylisoborneol and geosmin off-flavors and associated phytoplankton populations also are discussed. Results of this study suggest that one-year-old biofloc water can be used without adverse impact for a second year of channel catfish production in the biofloc system.
\end{abstract}

\section{Introduction}

Phytoplankton and bacterial uptake consume excreted feed nitrogen during start-up of a new photoautotrophic-chemoautotrophic, i.e., mixotrophic, biofloc technology (BFT) system for freshwater finfish production. Large increases (spikes) in total ammonia-nitrogen $\left(\mathrm{NH}_{4}-\mathrm{N}\right)$ concentration as high as $14.5 \mathrm{mg} / \mathrm{L}$ followed by up to $5 \mathrm{mg} / \mathrm{L}$ of nitrite-nitrogen $\left(\mathrm{NO}_{2}-\mathrm{N}\right)$ concentration occur within the first four to six weeks of system start-up (Green et al., 2019b). During this period, pH and temperature in outdoor mixotrophic BFT tanks often range from $\mathrm{pH} 8$ to 9 and 20 to $25{ }^{\circ} \mathrm{C}$, respectively (Green et al., 2014), and 4 to $36 \%$ of total ammonia-nitrogen concentration will be present as unionized ammonia, which can result in acute ammonia toxicity. Similarly, high nitrite-nitrogen concentration can induce methemoglobinemia (Huey et al., 1980; Schwedler and Tucker, 1983). Subsequently, the increase in nitrate-nitrogen concentration and concomitant decrease in total alkalinity signals that nitrification is established fully. The time delay to reach full nitrification may be related to the cumulative nitrogen input. Nitrification in a freshwater mixotrophic BFT production system was reported after nitrogen input of $27.4 \mathrm{~g} / \mathrm{m}^{3}$ for channel catfish (Ictalurus punctatus; Green, 2010; hereafter, catfish) culture or about $37 \mathrm{~g} / \mathrm{m}^{3}$ for hybrid tilapia (Oreochromis aureus x $O$. niloticus; Green et al., 2019b) culture. Once nitrification is established fully, total ammonia-nitrogen and nitrite-nitrogen concentrations generally remain below $0.5 \mathrm{mg} / \mathrm{L}$ despite high feed input to the densely stocked culture organisms (Green et al., 2014, 2019b).

Total suspended solids (TSS) concentration increases linearly in a mixotrophic BFT production system in response to high feed input (Green et al., 2014). During production of stocker-size (ca. $150 \mathrm{~g} / \mathrm{fish}$ ) catfish in the BFT system without solids removal, high TSS

\footnotetext{
* Corresponding author.

E-mail address: bart.green@usda.gov (B.W. Green).
} 
concentrations appeared to restrict daily feed intake and at a maximum of $2100 \mathrm{mg} / \mathrm{L}$ cause fish distress and limited mortality (Green et al., 2014). In a follow-on study, three levels of TSS control (no solids removal, flow rates of 0.9 or $2.9 \mathrm{~L} / \mathrm{min}$ through a settling chamber) were evaluated in the production of market-size ( $454 \mathrm{~g} / \mathrm{fish}$ ) catfish in the BFT system (Green et al., 2019a). In that study, maximum TSS concentration ranged from 1200 to $1410 \mathrm{mg} / \mathrm{L}$ when solids were not removed and ranged from 200 to $400 \mathrm{mg} / \mathrm{L}$ in the two solids removal treatments. Despite the significantly greater mean TSS concentration in the no-solids-removal treatment, no significant treatment differences among treatments were detected for total feed intake or any production variable; however, size distribution of fish harvested from the no-solidsremoval treatment were skewed toward smaller size-classes compared to the solids removal treatments.

When biofloc water from a just completed experiment to produce market-size catfish was re-used immediately to hold those fish over the winter, ammonia transformation in response to an ammonia-nitrogen spike was inversely related to mean water temperature from 3 to $12{ }^{\circ} \mathrm{C}$ (Green, 2015). No lag in ammonia bio-transformation was observed when feeding of fish resumed in mid-March at daily rations ranging from 47 to $69 \mathrm{~g} / \mathrm{m}^{3}$ and resultant changes in $\mathrm{NH}_{4}-\mathrm{N}$ and $\mathrm{NO}_{2}-\mathrm{N}$ concentrations were $<0.1 \mathrm{mg} / \mathrm{L}$. Thus, re-using biofloc water for more than one production cycle or season obviates the time required to establish a new, fully-functional biofloc with its associated $\mathrm{NH}_{4}-\mathrm{N}$ and $\mathrm{NO}_{2}-\mathrm{N}$ spikes. Few published studies (Krummenauer et al., 2014; Prangnell et al., 2016) were found on the re-use of biofloc water for a subsequent production cycle despite anecdotal reports. In these studies, biofloc water from a 62 to 120-d Pacific white shrimp (Litopenaeus vannamei; hereafter, shrimp) production cycle was used successfully to grow shrimp in a follow-on 30 to 108-d study. However, no study was found on using one-year-old biofloc water for a second year of production.

Accumulation of minerals, particularly cadmium, copper, and zinc, is a concern where culture water is re-used with little or no make-up water for multiple production cycles because mineral concentrations may reach toxic levels (Colt, 2006). The minerals in formulated feed and source water and from the corrosion of plumbing are sources of minerals in water re-use production systems. In addition to mineral accumulation in intensive recirculating aquaculture system (RAS) water, minerals may bioaccumulate in culture animal tissue, particularly edible tissue. Marbled eel (Anguilla marmorata) grown in traditional concrete ponds or RAS generally had significantly lower trace mineral concentrations in muscle tissue compare to eels grown in a BFT system (Li et al., 2018). Although there is published data on pondreared catfish fillet mineral concentration (e.g., Nettleton et al., 1990; Clement and Lovell, 1994; Li et al., 2013), data on mineral content of catfish grown in the BFT system is lacking.

The objectives of the present experiment were to compare the effect of new, unused water and year-old used biofloc water on catfish production characteristics and water quality in the BFT production system.

\section{Materials and methods}

\subsection{Experimental design, tank management, fish, and feeding}

A completely randomized design was used in triplicate outdoor wood-framed BFT production tanks for channel catfish production to evaluate the following treatments: 1) one-year old BFT water that contained low TSS concentration (Old-Lo treatment); 2) one-year old BFT water that contained high TSS concentration (Old-Hi treatment); and, 3) newly (New) established BFT water. The used biofloc water originated from an initial study that evaluated solids control in catfish BFT culture (Green et al., 2019a) and this water then was re-used immediately to evaluate low- and high-TSS BFT water for holding marketsize fish through the winter (Green, 2015), before finally being re-used immediately for the present study. The BFT system started at the beginning of this experiment utilized the new biofloc water. Old versus new biofloc waters, low- versus high-TSS old biofloc waters, and old versus new low-TSS waters were the planned comparisons evaluated. Each tank (18.6 m², $15.7 \mathrm{~m}^{3}$; described in detail by Green et al., 2014) was equipped with a side-stream 130-L (117-L working volume) conical-bottom settling chamber that was operated $(3.4 \mathrm{~L} / \mathrm{min}$ flow rate) beginning when TSS concentration approximated $400 \mathrm{mg} / \mathrm{L}$ (Green et al., 2014) and continuing as needed to maintain 300 to $400 \mathrm{mg} / \mathrm{L}$ TSS. Settling chambers were operated for two consecutive days (mean $=49.7 \mathrm{~h}$ ) each time they were activated. New treatment settling chambers were operated on average for significantly fewer $(P=.011)$ total hours $(725.8 \mathrm{~h}$ ) than were those in the Old-Lo treatment $(878.2 \mathrm{~h})$. Total suspended solids were removed from New and Old-Lo treatment tanks, but not from Old-Hi treatment tanks. Water was added to tanks only to replace losses to evaporation and draining of settling chambers.

Tanks in the New treatment were filled 9 days before stock out with groundwater $\left(226 \mathrm{mg} / \mathrm{L}\right.$ as $\mathrm{CaCO}_{3}$ total alkalinity) and, in order to stimulate the phytoplankton bloom, were each seeded with water $\left(2.3 \mathrm{~m}^{3}\right)$ from a pond with phytoplankton bloom. Each New treatment tank was fertilized with a total of $0.14 \mathrm{~kg}$ urea (46-0-0, N-P-K), $0.49 \mathrm{~kg}$ 9-27-0 (N-P-K), and $2 \mathrm{~kg}$ organic carbon (dried molasses and beet pulp) each made as one to two applications from day -9 to day 21 of the study.

Livestock salt ( $2.3 \mathrm{~kg} / \operatorname{tank})$ was added to each tank to ensure chloride concentration exceeded $100 \mathrm{mg} / \mathrm{L}$. Total alkalinity and $\mathrm{pH}$ in tank water were maintained by as-need additions of feed-grade sodium bicarbonate according to Loyless and Malone (1997).

Fingerling catfish (47.5 $\pm 0.8 \mathrm{~g} /$ fish; mean $\pm \mathrm{SD})$ were stocked into tanks at $13.5 \mathrm{fish} / \mathrm{m}^{2}\left(16 \mathrm{fish} / \mathrm{m}^{3}\right.$ ) and initial biomass averaged $0.76 \pm 0.2 \mathrm{~kg} / \mathrm{m}^{3}$. Animal care and research protocol were approved by the Institutional Animal Care and Use Committee and conformed to ARS Policies and Procedures 130.4 and 635.1. Fish were fed a commercial formulated feed (32\% crude protein, $2.5 \%$ lipid) to apparent satiation six days per week and the quantity recorded. Feed conversion ratio (FCR) was calculated for each tank as the total quantity of feed fed (dry matter basis) divided by the net (wet) weight of fish harvested.

At stocking, 10 fish were selected arbitrarily from the initial population, euthanized, and frozen individually for later analysis of wholebody mineral content. At harvest, condition indices (hepatosomatic index, HSI; intraperitoneal fat, IPF; and, muscle ratio, MR) were measured on arbitrary subsets of five euthanized fish from the 60-fish sample from each tank. An additional subset of five fish from each 60fish sample were euthanized and frozen for later analysis of whole-body composition.

\subsection{Fish, tissue, and feed sampling analyses}

Initial and final fish whole-bodies, final muscle samples (1 fillet/ fish), and feed samples were prepared as described previously (Rawles et al., 2018). Samples of at least 75 fish/tank to estimate growth trajectories, taken on days $29,53,85,113,141$, and 169 were weighed in bulk as lots of 15-25 fish each and returned alive to their respective tank. Tanks were harvested after $181 \mathrm{~d}$. For each tank, a minimum of 60 fish/tank were weighed individually and remaining fish were counted and weighed in bulk. Initial and final fish whole-body samples were analyzed individually for proximate composition according to standard methods (AOAC (Association of Official Analytical Chemists), 2006). Additionally, initial and final fish whole-bodies, final muscle samples, and feed samples were sent to the Central Analytical Lab, Center of Excellence for Poultry Science, University of Arkansas, Fayetteville, AR USA, for mineral analysis (aluminum, antimony, barium, boron, cadmium, calcium, chromium, cobalt, copper, iron, lead, magnesium, manganese, molybdenum, nickel, phosphorus, potassium, selenium, sodium, titanium, vanadium, and zinc) by inductively coupled plasma optical emission spectroscopy. Apparent whole-body retention of feed minerals was calculated on a dry matter basis as (net mineral 
gain $\times 100) /($ mineral fed $)$.

\subsection{MIB and geosmin analyses}

On days $40,82,103,152$, and 173 water samples were collected from each tank for analysis of the common off-flavor compounds 2methylisoborneol (MIB) and geosmin as described previously (Schrader et al., 2011) and for phytoplankton identification and enumeration as described by Schrader et al. (2016). One fillet from each of five fish per tank, collected during the harvest MR analysis, was placed in an individually labeled plastic bag, vacuum sealed, and stored frozen. All samples were sent for analysis by next-day delivery to the USDA-ARS Natural Products Utilization Research Unit, University, MS USA. The instrumental limit of detection was 1 part per trillion for each compound.

\subsection{Water quality analyses}

Dissolved oxygen and water temperature in each tank were monitored continuously as described by Green et al. (2019a). Water samples were collected weekly from each tank between 0700 and $0800 \mathrm{~h}$ and analyzed immediately as described by Rawles et al. (2018) for $\mathrm{NH}_{4}-\mathrm{N}$, $\mathrm{NO}_{2}-\mathrm{N}, \mathrm{NO}_{3}-\mathrm{N}, \mathrm{PO}_{4}-\mathrm{P}$, total alkalinity, total suspended solids (TSS), chlorophyll $a$, and $\mathrm{pH}$. Water samples also were collected from each tank one day before stock-out and one day before harvest, filtered through a $0.2-\mu \mathrm{m}$ membrane filter, and sent to the Water Quality Lab, Arkansas Water Resources Center, University of Arkansas, Fayetteville, AR USA, for analysis by inductively coupled plasma optical emission spectroscopy of dissolved minerals (aluminum, barium, beryllium, boron, cadmium, calcium, cobalt, copper, iron, lead, magnesium, manganese, molybdenum, nickel, phosphorus, potassium, sodium, silicon, sulfur, and zinc).

\subsection{Statistical analyses}

Normality and homoscedasticity of data were confirmed by the Shapiro-Wilk test and Levene's test, respectively, before continuing statistical analyses using SAS version 9.4. Mixed models analysis of variance (ANOVA), $t$-test, and linear regression analysis were used to analyze fish production, compositional indices, water quality, flavor, and mineral data. A generalized linear mixed models repeated measures ANOVA [covariance structure selected as described by Gbur et al., 2012] was used to analyze water quality variable concentrations, feed consumption, phytoplankton abundance, and MIB and geosmin concentrations over time. The CONTRAST statement or all-pairwise means comparison of least squares means was performed using the DIFF option with the Tukey adjustment of $P$ values. Percent data were arcsin transformed before data analysis (Sokal and Rohlf, 1995). Differences among response variables were declared significant at $P \leq 0.05$.

\section{Results}

\subsection{Fish and feed performance, and condition indices}

Production variables did not differ significantly between New and Old (water) treatments, nor between the Old-Lo and Old-Hi treatments (Table 1). Gross and net fish yield averaged 10.2 and $9.4 \mathrm{~kg} / \mathrm{m}^{3}$, respectively. Total feed consumption averaged $12.8 \mathrm{~kg} / \mathrm{m}^{3}$ across treatments and results of repeated measures ANOVA did not detect significant differences $(P>0.05)$ among treatments for daily feed consumption throughout the experiment. Feed conversion ratio averaged 1.36. At harvest fish averaged $641.6 \mathrm{~g} /$ fish and $69.0 \%$ of the fish population attained market size ( $454 \mathrm{~g} /$ fish). Liver size (HSI), muscle ratio, intraperitoneal fat, and whole-body protein, lipid, and moisture did not differ significantly among treatments.
Table 1

Least squares means and pooled (SEp) for growth, feed performance, and composition indices of channel catfish, (initial weight: $47.5 \pm 0.8 \mathrm{~g} / \mathrm{fish}$ ) reared to market size in outdoor biofloc production technology tanks. ${ }^{\text {a }}$

\begin{tabular}{lllllll}
\hline & \multicolumn{2}{l}{ Treatment } & & & \multirow{2}{*}{ ANOVA } \\
\cline { 2 - 3 } Response $^{\mathrm{b}}$ & New & Old-Lo & Old-Hi & & SE $p$ & Pr $>F^{\mathrm{c}}$ \\
\hline GFY & 10.1 & 10.1 & 10.4 & & 0.3 & 0.731 \\
NFY & 9.3 & 9.4 & 9.6 & & 0.3 & 0.711 \\
Survival & 99.6 & 99.9 & 99.3 & & 0.3 & 0.467 \\
Avg wt & 634.3 & 631.6 & 658.8 & & 20.1 & 0.600 \\
Gain & 1237.3 & 1221.8 & 1292.6 & & 33.6 & 0.357 \\
\% $>$ 454 g & 69.9 & 66.7 & 70.5 & & 3.7 & 0.746 \\
Total feed & 12.7 & 12.7 & 13.1 & & 0.4 & 0.749 \\
FCR & 1.37 & 1.36 & 1.35 & & 0.03 & 0.957 \\
IPF & 3.33 & 3.25 & 3.45 & & 0.23 & 0.763 \\
MR & 53.8 & 52.0 & 50.2 & & 0.02 & 0.390 \\
HSI & 1.64 & 1.52 & 1.71 & & 0.11 & 0.514 \\
Protein & 15.9 & 15.7 & 15.7 & & 0.3 & 0.770 \\
Lipid & 12.9 & 13.5 & 13.2 & & 0.4 & 0.725 \\
Moisture & 68.3 & 67.9 & 68.5 & 0.6 & 0.811 \\
\hline
\end{tabular}

${ }^{\text {a }} \mathrm{N}=3$ replicate tanks.

GFY: gross fish yield $\left(\mathrm{kg} / \mathrm{m}^{3}\right)$ after 188-189 days; NFY: net fish yield (kg/ $\mathrm{m}^{3}$ ); Survival (\%); Avg wt: average fish weight $(\mathrm{g})$ at harvest; Gain $(\%)=($ final weight - initial weight) $* 100 /$ initial weight; $\%>454 \mathrm{~g}$ : percent of fish weighing $>454 \mathrm{~g}$ at harvest; Total feed $\left(\mathrm{kg} / \mathrm{m}^{3}\right.$, dry weight basis) consumed; FCR: feed conversion ratio $=\mathrm{g}$ dry feed consumed/g weight gained; IPF: intraperitoneal fat $(\%)=$ intraperitoneal fat mass * 100/fish mass; MR: muscle ratio $(\%)=$ fillet with rib mass * 100/fish mass; HSI: hepatosomatic index $(\%)=$ liver mass $\times 100 /$ fish mass; whole body protein, lipid, and moisture (\%, fresh-weight).

ANOVA, $\operatorname{Pr}>$ F. LS means in the same row with different letters are different $(P \leq 0.05)$.

\subsection{Water quality dynamics}

At the start of the experiment the following water quality variables concentrations (range) did not differ significantly among treatments: $\mathrm{NO}_{2}-\mathrm{N} \quad(0.02-0.11 \mathrm{mg} / \mathrm{L} ; \quad P=0.362)$ and chlorophyll $a$ (640.4-1689.9 mg/m $\left.\mathrm{m}^{3} ; P=0.097\right)$. Mean New treatment initial $\mathrm{NH}_{4}-\mathrm{N}$ concentration $(0.01 \mathrm{mg} / \mathrm{L})$ was significantly lower $(P=0.002)$ than in the Old-Lo $(0.07 \mathrm{mg} / \mathrm{L})$ or Old-Hi $(0.11 \mathrm{mg} / \mathrm{L})$ treatments, which did not differ. Mean concentration of $\mathrm{NO}_{3}-\mathrm{N}, \mathrm{PO}_{4}-\mathrm{P}$, and TSS in the Old-Hi treatment $(87.24,22.68$, and $552.22 \mathrm{mg} / \mathrm{l}$, respectively) was significantly greater $(P<0.001,<0.001$, and $<0.001$, respectively) than in the Old-Lo treatment $(53.60,10.48$, and $312.78 \mathrm{mg} / \mathrm{L}$, respectively), which was significantly greater than in the New treatment $(0.91,1.57,68.00 \mathrm{mg} / \mathrm{L}$, respectively). Initial mean total alkalinity in the New treatment $\left(226.3 \mathrm{mg} / \mathrm{L}\right.$ as $\left.\mathrm{CaCO}_{3}\right)$ was significantly greater $(P=0.001)$ than in the Old-Lo $\left(90.8 \mathrm{mg} / \mathrm{L}\right.$ as $\left.\mathrm{CaCO}_{3}\right)$ or Old-Hi $\left(93.76 \mathrm{mg} / \mathrm{L}\right.$ as $\mathrm{CaCO}_{3}$ ), which did not differ.

Mean dissolved oxygen concentration was $7.43,7.63$, or $7.51 \mathrm{mg} / \mathrm{L}$ (89.4, 91.4, or $89.9 \%$ saturation) in the New, Old-Lo, or Old-Hi treatments, respectively, and did not differ significantly among treatments $(P=0.384)$. Corresponding mean minimum and maximum DO concentrations were $6.9,7.0$, and $6.9 \mathrm{mg} / \mathrm{L}$, and $11.0,11.4$, and $11.7 \mathrm{mg} / \mathrm{L}$, respectively. Water temperature did not differ significantly $(P=0.466)$ among treatments and averaged $24.7,24.4$, or $24.4^{\circ} \mathrm{C}$ in the New, OldLo, or Old-Hi treatments, respectively. Corresponding mean minimum and maximum temperatures concentrations were $23.1,22.8$, or $22.8^{\circ} \mathrm{C}$, and $30.8,30.4$, or $30.6{ }^{\circ} \mathrm{C}$, respectively.

Mean $\mathrm{NO}_{2}-\mathrm{N}, \mathrm{NO}_{3}-\mathrm{N}, \mathrm{PO}_{4}-\mathrm{P}$, TSS, and total alkalinity concentrations differed significantly among treatments (Table 2). Mean $\mathrm{NH}_{4}-\mathrm{N}$ and $\mathrm{NO}_{2}-\mathrm{N}$ concentrations in the New treatment followed the typical nitrification start-up pattern (Fig. 1). Mean New treatment $\mathrm{NH}_{4}-\mathrm{N}$ concentration spiked to $1.52 \mathrm{mg} / \mathrm{L}$ on day 14 , significantly greater $(P=0.033)$ than in the Old-Lo and Old-Hi treatments which each averaged $0.08 \mathrm{mg} / \mathrm{L}$ and did not differ significantly. On day 28 , mean 
Table 2

Least squares means and pooled (SEp) for water quality variables for channel catfish, (initial weight: $47.5 \pm 0.8 \mathrm{~g} /$ fish) reared to market size in outdoor biofloc production technology tanks. ${ }^{\mathrm{a}}$

\begin{tabular}{lllllll}
\hline & \multicolumn{3}{l}{ Treatment } & & & \multicolumn{2}{c}{ ANOVA } \\
\cline { 2 - 3 } Response $^{\mathrm{b}}$ & New & Old-Lo & Old-Hi & & SE $p$ & Pr $>F^{c}$ \\
\hline $\mathrm{NH}_{4}-\mathrm{N}$ & 0.21 & 0.15 & 0.16 & & 0.03 & 0.359 \\
$\mathrm{NO}_{2}-\mathrm{N}$ & $0.39^{\times}$ & $0.16^{\mathrm{xy}}$ & $0.05^{\mathrm{y}}$ & & 0.07 & 0.046 \\
$\mathrm{NO}_{3}-\mathrm{N}$ & $69.46^{\mathrm{y}}$ & $94.58^{\mathrm{y}}$ & $133.66^{\times}$ & & 8.22 & 0.004 \\
$\mathrm{PO}_{4}-\mathrm{P}$ & $11.68^{\mathrm{z}}$ & $20.20^{\mathrm{y}}$ & $29.73^{\times}$ & & 1.70 & 0.001 \\
$\mathrm{TSS}$ & $355.39^{\mathrm{y}}$ & $409.89^{\mathrm{y}}$ & $986.67^{\times}$ & & 31.54 & $<0.001$ \\
$\mathrm{Chl} a$ & 929.5 & 1432.2 & 1649.2 & & 167.3 & 0.055 \\
$\mathrm{~T} \mathrm{Alk}$ & $108.2^{\times}$ & $94.6^{\mathrm{y}}$ & $108.2^{\times}$ & & 2.9 & 0.025 \\
\hline
\end{tabular}

a $\mathrm{N}=3$ replicate tanks.

b $\mathrm{NH}_{4}-\mathrm{N}$, total ammonia-nitrogen, $\mathrm{mg} / \mathrm{L} ; \mathrm{NO}_{2}-\mathrm{N}$, nitrite-nitrogen, mg/L; $\mathrm{NO}_{3}-\mathrm{N}$, nitrate-nitrogen, $\mathrm{mg} / \mathrm{L} ; \mathrm{PO}_{4}-\mathrm{P}$, soluble reactive phosphate, $\mathrm{mg} / \mathrm{L}$; total suspended solids, $\mathrm{mg} / \mathrm{L}$; Chl $a$, chlorophyll $a, \mathrm{mg} / \mathrm{m}^{3}$; T Alk, total alkalinity, $\mathrm{mg} / \mathrm{L}$ as $\mathrm{CaCO}_{3}$.

ANOVA, $\mathrm{Pr}>\mathrm{F}$. LS means in the same row with different letters are different $(P \leq 0.05)$.

New treatment mean $\mathrm{NO}_{2}-\mathrm{N}$ concentration spiked to $2.68 \mathrm{mg} / \mathrm{L}$, but did not differ significantly $(P=0.383)$ from the Old-Lo $(0.10 \mathrm{mg} / \mathrm{L})$ or Old$\mathrm{Hi}(0.03 \mathrm{mg} / \mathrm{L})$ treatments. Mean TSS beginning on day 42 through the end of the experiment was significantly greater $(P<0.05)$ in the OldHi treatment than in the New or Old-Lo treatments, which did not differ significantly (Fig. 1).

Once solids removal was active in the New and Old-Lo treatments (day 34) the rate at which $\mathrm{NO}_{3}-\mathrm{N}$ concentration increased over time differed significantly $(P<0.05)$ among treatments. Mean $\mathrm{NO}_{3}-\mathrm{N}$ accumulation rate in the New $(0.88 \mathrm{mg} / \mathrm{L}-\mathrm{d})$ and Old-Hi $(0.85 \mathrm{mg} / \mathrm{L}-\mathrm{d})$ treatments did not differ and were significantly greater $(P=0.001)$ than for the Old-Lo $(0.65 \mathrm{mg} / \mathrm{L}-\mathrm{d})$ treatment. However, the mean regression line intercept for the New $(-14.6 \mathrm{mg} / \mathrm{L})$ treatment was significantly lower $(P=0.003)$ than for the Old-Lo $(31.2 \mathrm{mg} / \mathrm{L})$ and OldHi (48.1 mg/L) treatments, which did not differ.

Sodium bicarbonate addition varied significantly $(P=0.038)$ among treatments and was positively correlated to mean $\mathrm{NO}_{3}-\mathrm{N}$ concentration $(P<0.001)$. Mean sodium bicarbonate addition to Old-Hi tanks $\left(913 \mathrm{~g} / \mathrm{m}^{3}\right)$ was significantly greater than mean addition to New tanks $\left(411 \mathrm{~g} / \mathrm{m}^{3}\right)$, while mean addition to Old-Lo tanks $\left(529 \mathrm{~g} / \mathrm{m}^{3}\right) \mathrm{did}$ not differ significantly from the other two treatments.

Significantly more $(P<0.001)$ solids were removed from Old-Lo tanks (mean $=39.1 \mathrm{~kg}$ dry matter, dm) compared to New tanks $(27.6 \mathrm{~kg} \mathrm{dm})$. Because Old-Lo treatment settling chambers were drained more frequently, mean total water discharge $\left(3.6 \mathrm{~m}^{3}\right)$ was significantly greater $(P<0.001)$ than from New treatment settling chambers $\left(2.9 \mathrm{~m}^{3}\right)$. Significantly more solids were drained in June $(P=0.008)$ and August $(P=0.011$ ) from Old-Lo (mean $=4.47 \mathrm{~kg} \mathrm{dm}$ and $8.16 \mathrm{~kg} \mathrm{dm}$, respectively) compared to New (mean $=1.41 \mathrm{~kg} \mathrm{dm}$ and $3.37 \mathrm{~kg} \mathrm{dm}$, respectively) treatment settling chambers. Mean regression line slope for $\mathrm{NO}_{3}-\mathrm{N}$ accumulation during June (days 32 to 60 ) was significantly greater $(P=0.008)$ in the New $(1.27 \mathrm{mg} / \mathrm{L} / \mathrm{d})$ treatment compared to the Old-Lo $(0.42 \mathrm{mg} / \mathrm{L} / \mathrm{d})$ and Old-Hi $(0.67 \mathrm{mg} / \mathrm{L} / \mathrm{d})$ treatments, which did not differ. Although $\mathrm{NO}_{3}-\mathrm{N}$ accumulation rate in August (days 93 to 121 ) did not differ significantly ( $P=0.486$ ) among treatments, the New treatment rate $(1.77 \mathrm{mg} / \mathrm{L} / \mathrm{d})$ was $20.4 \%$ higher than the Old-Lo treatment rate $(1.47 \mathrm{mg} / \mathrm{L} / \mathrm{d})$.

\subsection{Mineral concentration of water, feed, and fish}

Aluminum, cadmium, chromium, lead, nickel, and selenium concentrations were below method detection limit in most or all water samples for all treatments. Cobalt concentration was below method detection limit in all final samples. Manganese and vanadium concentrations were below method detection limit in all initial samples. Final mineral mean concentrations in New treatment tank water generally were significantly greater than in initial samples except for barium and calcium which decreased significantly (Table 3). Like New treatment waters, barium final mean concentration in the Old-Lo and Old-Hi treatments was significantly lower than in initial water samples and calcium final concentration was significantly lower in the Old-Hi treatment. Final water sample mean concentrations of boron, magnesium, and potassium were significantly greater $(P<0.05)$ than their corresponding initial sample mean. Overall, the percentage change in trace mineral concentration between initial and final water samples tended to be larger in the New treatment.

Initial mean mineral concentrations in water varied significantly among treatments and generally were significantly lower $(P<0.05)$ in the New treatment compared to the Old treatments (Table 3). Mean initial boron, magnesium, and sodium concentration in the Old-Hi treatment was significantly higher $(P<0.05)$ than in Old-Lo treatment. Mean final concentrations of barium, calcium, iron, and zinc in the New and Old-Lo treatments did not differ significantly $(P>0.05)$ and were significantly greater $(P<0.05)$ than in the Old-Hi treatment (Table 3). Boron and magnesium concentrations in Old-Hi treatment final water samples were significantly greater $(P<0.05)$ than in the New or Old-Lo treatments, which did not differ significantly.

Detection of minerals in whole-bodies was variable (as reflected in the SEs) and mean mineral concentrations for initial fish and harvested fish from each treatment are shown in Table 4. Aluminum, and beryllium mean concentrations in initial and harvested fish whole bodies were below the method detection limit for each analysis. Cadmium concentration was below analysis method detection limit in initial fish, and in harvested fish in one replicate tank each from the New and OldHi and two replicate tanks from the Old-Lo treatment. Cobalt, cadmium, lead, and nickel were below analysis method detection limit in harvested fish in one replicate tank each from the New and Old-Hi and two replicate tanks from the Old-Lo treatment. Copper was below analysis method detection limit in an average of 3 harvested fish per replicate tank across treatments. Manganese was detected in all but one fish from New tanks, in 2 to 4 fish/tank in Old-Lo tanks, and 3 to 5 fish/ tank in Old-Hi tanks. Molybdenum and antimony were below analysis method detection limit in 2 to 4 fish in one replicate tank from each treatment. No significant differences were detected among treatments for any whole-body mineral concentration in harvested fish.

Mean mineral concentrations in feed are shown in Table 5. Only beryllium was below analysis method detection limit in feed. Apparent whole-body mineral retention in harvested fish ranged from 0 to $139 \%$ of minerals consumed as formulated feed (Table 5). Whole-body apparent mineral retention from feed did not differ significantly $(P>0.05)$ among treatments for any mineral.

Like whole-bodies, detection of minerals in fillet tissue was variable (as reflected in the SEs) and mean concentrations are shown in Table 6. Aluminum, barium, beryllium, cobalt, manganese, and nickel concentrations in fillet tissue from all treatments were below analysis method detection limit. Cadmium was detected in fillet meat from 1, 1 , and 2 fish in the New, Old-Lo, and Old-Hi treatments, respectively, and averaged $0.445 \pm 0.446(\mathrm{SD}) \mathrm{mg} / \mathrm{kg}$ dry matter overall. Copper was detected in 1 to 3 fish/tank in New tanks, 1 fish/tank in Old-Lo tanks, and in 4 fish from only one Old-Hi tank and averaged $0.545 \pm 0.495$ (SD) $\mathrm{mg} / \mathrm{kg}$ dry matter overall. Molybdenum mean concentration in fillet tissue from one tank each from the Old-Lo and Old-Hi treatments and in 4 fish from one New tank was below analysis method detection limit. Lead was detected only in a total of 8 fish in the New treatment, 2 fish in the Old-Lo treatment, and 6 fish in the Old-Hi treatment, and averaged $1.34 \pm 1.29(\mathrm{SD}) \mathrm{mg} / \mathrm{kg}$ dry matter overall. No significant differences $(P>0.05)$ were detected among treatments for fillet mineral concentrations. 


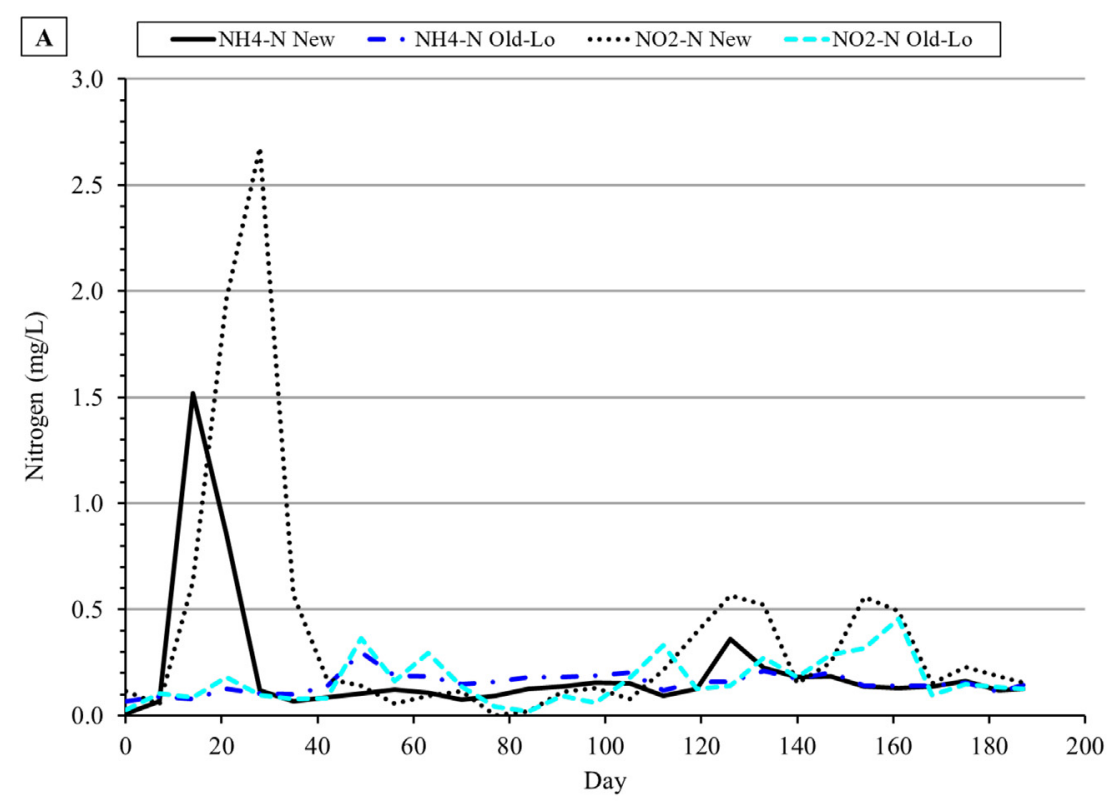

B

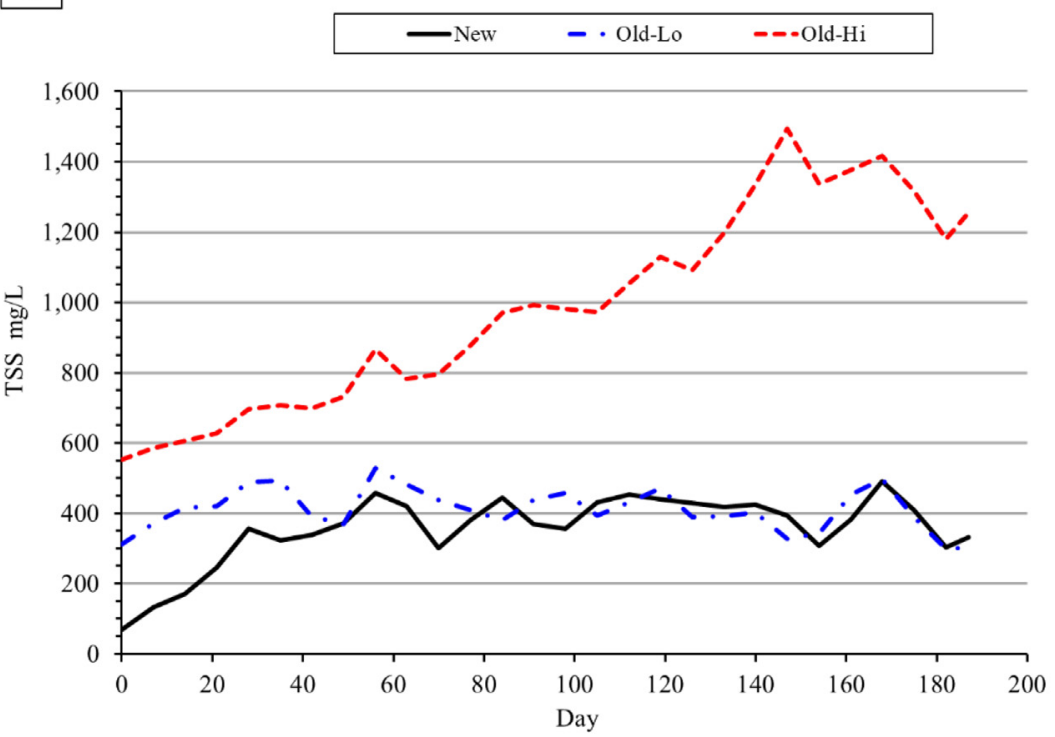

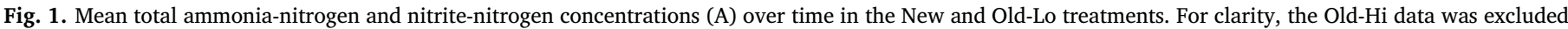

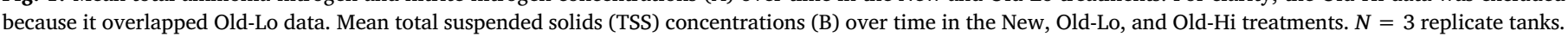

\subsection{MIB and geosmin concentrations, and phytoplankton dynamics}

Mean MIB concentrations in tank water did not differ significantly $(P>0.05)$ among sample dates within treatment (New, $P=0.784$; Old-Lo, $P=0.152$; Old-Hi, $P=0.705$ ), and generally were $<20 \mathrm{ng} / \mathrm{L}$ except for the day 173 sample (Fig. 2). No significant differences were detected for MIB among treatments within date $(P=0.142-0.814)$. Mean geosmin concentrations in tank water did not differ significantly $(P>0.05)$ among sample dates within treatment (New, $P=0.064$; Old-Lo, $P=0.064$; Old-Hi, $P=0.427$ ), and were $<100 \mathrm{ng} / \mathrm{L}$ except for New treatment day 173 and 189 samples (Fig. 2).

At harvest, MIB concentrations in fillets averaged 41.7, 20.4, and $20.0 \mathrm{ng} / \mathrm{kg}$ ( $\mathrm{SE}=15.5 \mathrm{ng} / \mathrm{kg})$ in the New, Old-Lo, and Old-Hi treatments, respectively, and did not differ significantly $(P=0.559)$. Fillet MIB concentration exceeded $100 \mathrm{hg} / \mathrm{kg}$ in only one fish in one tank each of the New and Old-Lo treatment. Mean geosmin concentrations in fillets did not differ significantly $(P=0.269)$ among treatments and were $959.4,132.6$, and $48.1 \mathrm{ng} / \mathrm{kg}(\mathrm{SE}=392.3 \mathrm{ng} / \mathrm{kg}$ ) in the New, Old-Lo, and Old-Hi treatments, respectively. Fillet geosmin concentration exceeded $200 \mathrm{ng} / \mathrm{kg}$ in $67 \%$ of fish tested in the New treatment, $20 \%$ of fish tested in the Old-Lo treatment, and no fish in the Old-Hi treatment.

Total phytoplankton counts varied significantly among sample dates in the New $(P=0.001)$ and Old-Lo $(P=0.004)$ treatments, but not in the Old-Hi $(P=0.597)$ treatment (Fig. 3). Chlorophyte abundance in the day 40 sample was significantly higher $(P=0.004)$ in the New and Old-Lo treatments than in the Old-Hi treatment. Mean chlorophyte abundance on day 82 in the Old-Lo treatment was significantly greater $(P=0.026)$ than in the New and Old-Hi treatments. No other treatment differences were detected within sample dates for the remaining phytoplankton taxa.

Phytoplankton populations in all treatments included species from Chlorophyta, Cyanophyta, Bacillariophyta, Euglenophyta, and Chrysophyta (Table 7). Apart from the day $40 \mathrm{New}$ and Old-Lo 
Table 3

Least squares mean initial and final mineral concentrations $(\mathrm{mg} / \mathrm{L})$ in biofloc water from New, Old-Lo, and Old-Hi treatments. ${ }^{\S}$

\begin{tabular}{|c|c|c|c|c|c|c|}
\hline \multirow[b]{2}{*}{ Variable } & \multicolumn{2}{|l|}{ New } & \multicolumn{2}{|l|}{ Old-Lo } & \multicolumn{2}{|l|}{ Old-Hi } \\
\hline & Initial & Final & Initial & Final & Initial & Final \\
\hline Barium & $0.178^{\mathrm{a}}$ & $0.018^{* \mathrm{x}}$ & $0.051^{\mathrm{b}}$ & $0.020^{* x}$ & $0.067^{\mathrm{b}}$ & $0.005^{* \mathrm{y}}$ \\
\hline Boron & $0.309^{\mathrm{b}}$ & $0.698^{* \mathrm{y}}$ & $0.331^{\mathrm{b}}$ & $0.764^{* y}$ & $0.429^{\mathrm{a}}$ & $1.122^{* \mathrm{x}}$ \\
\hline Calcium & $30.957^{\mathrm{a}}$ & $14.568^{* x}$ & $14.419^{b}$ & $11.867^{\times}$ & $18.065^{b}$ & $8.167^{*} \mathrm{y}$ \\
\hline Chromium & $\dagger$ & $\dagger$ & $\dagger$ & $\dagger$ & $\dagger$ & 0.006 \\
\hline Cobalt & 0.006 & $\dagger$ & 0.005 & $\dagger$ & 0.005 & $\dagger$ \\
\hline Copper & 0.012 & 0.023 & 0.017 & 0.024 & 0.016 & $0.026^{*}$ \\
\hline Iron & $\dagger$ & $0.031^{\times}$ & 0.018 & $0.033^{\times}$ & 0.012 & $0.017^{y}$ \\
\hline Magnesium & $7.692^{c}$ & $29.680^{* y}$ & $17.861^{\mathrm{b}}$ & $32.689^{* y}$ & $22.293^{\mathrm{a}}$ & $37.422^{* x}$ \\
\hline Manganese & $\dagger$ & 0.004 & $\dagger$ & 0.004 & $\dagger$ & 0.004 \\
\hline Molybdenum & 0.007 & 0.008 & 0.008 & 0.012 & 0.013 & 0.010 \\
\hline Nickel & $\dagger$ & $\dagger$ & $\dagger$ & $\dagger$ & $\dagger$ & 0.012 \\
\hline Phosphorus & $1.873^{\mathrm{b}}$ & $29.608 *$ & $13.496^{\mathrm{b}}$ & $36.707^{*}$ & $30.642^{\mathrm{a}}$ & 41.507 \\
\hline Potassium & $8.05^{\mathrm{b}}$ & $99.44^{* \mathrm{y}}$ & $57.03^{\mathrm{a}}$ & $118.60^{* \mathrm{x}}$ & $69.42^{\mathrm{a}}$ & $123.60^{* x}$ \\
\hline Sodium & $153.90^{c}$ & $335.60^{* x}$ & $237.80^{\mathrm{b}}$ & $314.00^{y}$ & $293.20^{\mathrm{a}}$ & $466.00^{\times}$ \\
\hline Titanium & $0.003^{\mathrm{b}}$ & 0.006 & $0.004^{\mathrm{a}}$ & $0.007^{*}$ & $0.004^{\mathrm{a}}$ & $0.007^{*}$ \\
\hline Vanadium & $\dagger$ & 0.011 & $\dagger$ & 0.011 & $\dagger$ & 0.012 \\
\hline Zinc & $0.002^{\mathrm{b}}$ & $0.023^{* \mathrm{xy}}$ & $0.024^{\mathrm{a}}$ & $0.028^{\times}$ & $0.027^{\mathrm{a}}$ & $0.013^{y}$ \\
\hline
\end{tabular}

abc initial means among treatments differ significantly $(P \leq 0.05)$.

${ }^{\mathrm{xyz}}$ final means among treatments differ significantly $(P \leq 0.05)$.

$\dagger$ Below method detection limit (chromium $=0.004 \mathrm{mg} / \mathrm{L}$; iron $=0.005 \mathrm{mg} / \mathrm{L}$; manganese $=0.001 \mathrm{mg} / \mathrm{L}$; nickel $=0.008 \mathrm{mg} / \mathrm{L}$; vanadium $=0.002 \mathrm{mg} / \mathrm{L}$ ).

${ }^{\S} N=3$ replicate tanks.

* Initial and final means within treatment differ significantly $(P \leq 0.05)$.

treatment samples where Chlorophyta comprised 46 to $60 \%$ of the total phytoplankton count, Cyanophyta predominated in all treatments across all sample dates. Jaaginema subtilissimum and Jaaginema angustissimum were the most-abundant cyanophytes and present in all treatment tanks on 4 to 5 sample dates. Lower abundance (200-500 natural units $/ \mathrm{mL}$ ) of Planktothrix agardhii were observed only in the day 40 sample in one New and two Old-Hi treatment tanks. No cyanophyte species known to produce MIB or geosmin were identified on any sample date. Commonly observed chlorophyte genera were Scenedesmus and Ankistrodesmus. Pennate diatoms were common in all tanks on 4 of 5 sample dates.

\section{Discussion}

\subsection{Fish and feed performance, and condition indices}

Biofloc production system water from a full season of catfish growout (Green et al., 2019a) that was used to maintain market-size fish over the winter (Green, 2015) was used successfully in the present study for a second year of catfish food-fish production. This is the first report of using biofloc water from the previous year for a second year of production. Whether the mixotrophic BFT production system was started fresh (New treatment) or utilized water from the previous year that differed significantly in initial TSS and chlorophyll $a$ concentrations (Old-Lo and Old-Hi treatments), catfish growth, feed performance, and compositional indices all responded similarly. In a 210-d BFT production system study where initial conditions (46.9-g fingerling, $0.74 \mathrm{~kg} / \mathrm{m}^{3}$ initial biomass) were like those of the current study, gross fish yield ranged from 7.6 to $8.7 \mathrm{~kg} / \mathrm{m}^{3}$, average weight from 540 to $590 \mathrm{~g}$ /fish, and FCRs from 1.6 to 1.7 (Green et al., 2019a). Gross fish yield ranged from 4.9 to $9.3 \mathrm{~kg} / \mathrm{m}^{3}$ in catfish BFT production system studies that were stocked with larger fingerlings or stocker-size fish (Schrader et al., 2011; Green et al., 2014).

Daily feed consumption in an earlier catfish BFT production study appeared to reach a stable asymptote at mean TSS concentrations ranging from 564 to $1683 \mathrm{mg} / \mathrm{L}$ (Green et al., 2014). Consequently, the authors of that study recommended maintaining TSS concentration between approximately 300 to $400 \mathrm{mg} / \mathrm{L}$ to ensure good catfish growth. A similar recommendation was offered for Pacific white shrimp grown in a BFT production system (Ray et al., 2010). Mean daily feed consumption was similar in all treatments throughout the present study despite differences in TSS concentrations among treatments and over time. Side-stream settling chambers were used to remove TSS from New and Old-Lo treatment tanks to maintain mean TSS from 300 to $400 \mathrm{mg}$ /

Table 4

Least squares means ( \pm SE) for whole-body mineral concentration in initial and harvested catfish in the New, Old-Lo, and Old-Hi treatments. ${ }^{2}$

\begin{tabular}{|c|c|c|c|c|c|}
\hline \multirow[b]{3}{*}{ Mineral } & \multirow{2}{*}{$\begin{array}{l}\text { Initial } \\
\text { Fish }^{\mathrm{b}}\end{array}$} & \multicolumn{3}{|l|}{ Harvested fish } & \multirow{3}{*}{$\begin{array}{l}\text { ANOVA } \\
P r>F^{\mathrm{d}}\end{array}$} \\
\hline & & New & Old-Lo & Old-Hi & \\
\hline & & \multicolumn{2}{|c|}{$\mathrm{mg} / \mathrm{kg}^{\mathrm{c}}$} & & \\
\hline Aluminum & $<0.100$ & $<0.100$ & $<0.100$ & $<0.100$ & \\
\hline Antimony & $15.2 \pm 6.6$ & $19.1 \pm 7.9$ & $9.9 \pm 7.8$ & $17.7 \pm 7.8$ & 0.682 \\
\hline Barium & $7.61 \pm 1.77$ & $0.95 \pm 0.33$ & $0.95 \pm 0.33$ & $0.87 \pm 0.33$ & 0.982 \\
\hline Beryllium & $<0.100$ & $<0.100$ & $<0.100$ & $<0.100$ & \\
\hline Boron & $89.4 \pm 6.1$ & $133.5 \pm 3.2$ & $133.5 \pm 3.2$ & $132.0 \pm 3.2$ & 0.934 \\
\hline Cadmium & $<0.100$ & $2.01 \pm 0.26$ & $1.97 \pm 0.37$ & $1.87 \pm 0.26$ & 0.936 \\
\hline Calcium & $39,961 \pm 6788$ & $15,896 \pm 2113$ & $15,044 \pm 2113$ & $13,217 \pm 2113$ & 0.675 \\
\hline Cobalt & $0.98 \pm 0.72$ & $2.14 \pm 0.30$ & $2.74 \pm 0.44$ & $1.94 \pm 0.30$ & 0.475 \\
\hline Copper & $6.72 \pm 4.38$ & $0.62 \pm 0.43$ & $1.15 \pm 0.52$ & $1.34 \pm 0.39$ & 0.477 \\
\hline Iron & $43.0 \pm 9.8$ & $41.5 \pm 5.2$ & $34.7 \pm 5.2$ & $51.6 \pm 5.2$ & 0.148 \\
\hline Lead & $9.05 \pm 4.01$ & $14.1 \pm 3.1$ & $8.6 \pm 3.5$ & $12.6 \pm 3.1$ & 0.585 \\
\hline Magnesium & $1259 \pm 158$ & $791 \pm 29$ & $792 \pm 29$ & $794 \pm 29$ & 0.997 \\
\hline Manganese & $12.2 \pm 6.7$ & $0.62 \pm 0.36$ & $0.78 \pm 0.41$ & $1.21 \pm 0.38$ & 0.546 \\
\hline Molybdenum & $3.12 \pm 1.02$ & $2.34 \pm 1.06$ & $1.49 \pm 1.05$ & $2.24 \pm 1.06$ & 0.831 \\
\hline Nickel & $2.02 \pm 0.99$ & $3.46 \pm 0.48$ & $4.18 \pm 0.68$ & $3.14 \pm 0.48$ & 0.573 \\
\hline Phosphorus & $25,760 \pm 3715$ & $12,638 \pm 1043$ & $12,165 \pm 1043$ & $11,470 \pm 1043$ & 0.740 \\
\hline Potassium & $12,965 \pm 945$ & $9866 \pm 166$ & $9626 \pm 166$ & $9888 \pm 166$ & 0.508 \\
\hline Sodium & $3947 \pm 392$ & $2686 \pm 71$ & $2629 \pm 71$ & $2667 \pm 71$ & 0.845 \\
\hline Silicon & $149.8 \pm 12.0$ & $66.5 \pm 4.6$ & $69.3 \pm 4.6$ & $71.6 \pm 4.6$ & 0.741 \\
\hline Sulfur & $6345 \pm 524$ & $4700 \pm 100$ & $4630 \pm 100$ & $4748 \pm 100$ & 0.718 \\
\hline Zinc & $110.3 \pm 10.6$ & $55.7 \pm 3.1$ & $56.3 \pm 3.1$ & $57.0 \pm 3.1$ & 0.958 \\
\hline
\end{tabular}

${ }^{\text {a }} \mathrm{N}=3$ replicate tanks.

b Mean \pm SD.

c Dry matter basis.

${ }^{d}$ ANOVA, $\mathrm{Pr}>\mathrm{F}$. LS means in the same row with different letters are different $(P \leq .05)$. 
Table 5

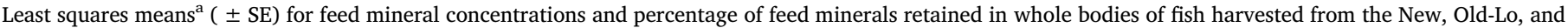
Old-Hi treatments.

\begin{tabular}{|c|c|c|c|c|c|}
\hline \multirow[b]{2}{*}{ Mineral } & \multirow{2}{*}{$\begin{array}{l}\text { Feed }^{\text {bc }} \\
(\mathrm{mg} / \mathrm{kg})\end{array}$} & \multicolumn{3}{|l|}{$\%$ Retained $^{\mathrm{c}}$} & \multirow{2}{*}{$\begin{array}{l}\text { ANOVA } \\
\operatorname{Pr}>F^{\mathrm{d}}\end{array}$} \\
\hline & & New & Old-Lo & Old-Hi & \\
\hline Aluminum & $46.3 \pm 23.5$ & $* \mathrm{e}$ & * & * & \\
\hline Antimony & $44.3 \pm 4.2$ & $9.9 \pm 4.5$ & $5.0 \pm 4.5$ & $9.3 \pm 4.0$ & 0.708 \\
\hline Barium & $5.0 \pm 0.1$ & $2.4 \pm 1.6$ & $2.5 \pm 1.6$ & $2.1 \pm 1.6$ & 0.986 \\
\hline Beryllium & $<0.100$ & $*$ & $*$ & * & \\
\hline Boron & $91.4 \pm 3.1$ & $35.1 \pm 1.3$ & $35.6 \pm 1.3$ & $34.7 \pm 1.3$ & 0.895 \\
\hline Cadmium & $4.1 \pm 0.3$ & $8.2 \pm 4.1$ & $4.0 \pm 4.1$ & $7.7 \pm 4.1$ & 0.742 \\
\hline Calcium & $2558 \pm 1159$ & $139.0 \pm 20.6$ & $133.0 \pm 20.6$ & $113.8 \pm 20.6$ & 0.682 \\
\hline Cobalt & $5.6 \pm 0.6$ & $6.1 \pm 3.5$ & $3.8 \pm 3.5$ & $5.6 \pm 3.5$ & 0.889 \\
\hline Copper & $13.1 \pm 1.0$ & $0.2 \pm 0.8$ & $1.7 \pm 0.8$ & $0.9 \pm 0.8$ & 0.493 \\
\hline Iron & $1031 \pm 144$ & $0.9 \pm 0.1$ & $0.8 \pm 0.1$ & $1.2 \pm 0.1$ & 0.145 \\
\hline Lead & $26.0 \pm 2.4$ & $8.4 \pm 4.3$ & $4.2 \pm 4.3$ & $7.5 \pm 4.3$ & 0.769 \\
\hline Magnesium & $3554 \pm 845$ & $4.9 \pm 0.2$ & $5.0 \pm 0.2$ & $4.9 \pm 0.2$ & 0.948 \\
\hline Manganese & $60.7 \pm 2.5$ & $0 \pm 0.1$ & $0 \pm 0.1$ & $0.2 \pm 0.1$ & 0.547 \\
\hline Molybdenum & $8.2 \pm 0.8$ & $6.3 \pm 3.2$ & $3.9 \pm 3.2$ & $6.0 \pm 3.2$ & 0.855 \\
\hline Nickel & $12.1 \pm 1.8$ & $4.5 \pm 2.5$ & $2.6 \pm 2.5$ & $4.1 \pm 2.5$ & 0.859 \\
\hline Phosphorus & $8141 \pm 781$ & $33.8 \pm 2.8$ & $32.8 \pm 2.8$ & $30.3 \pm 2.8$ & 0.690 \\
\hline Potassium & $13,216 \pm 1796$ & $17.0 \pm 0.4$ & $16.8 \pm 0.4$ & $17.0 \pm 0.4$ & 0.927 \\
\hline Silicon & $180.9 \pm 39.4$ & $7.8 \pm 0.6$ & $8.3 \pm 0.6$ & $8.5 \pm 0.6$ & 0.757 \\
\hline Sodium & $803 \pm 131$ & $75.0 \pm 1.7$ & $74.4 \pm 1.7$ & $74.4 \pm 1.7$ & 0.956 \\
\hline Sulfur & $3302 \pm 200$ & $32.6 \pm 0.8$ & $32.6 \pm 0.8$ & $33.0 \pm 0.8$ & 0.926 \\
\hline Zinc & $445.3 \pm 5.8$ & $2.8 \pm 0.1$ & $2.8 \pm 0.1$ & $2.9 \pm 0.1$ & 0.889 \\
\hline
\end{tabular}

a, b, c, d See Table 4 footnotes.

e $*$ Insufficient data.

Table 6

Least squares means ( \pm SE) for fillet mineral concentration in catfish harvested from the New, Old-Lo, and Old-Hi treatments. ${ }^{\text {a }}$

\begin{tabular}{lllll}
\hline & New & Old-Lo & Old-Hi & ANOVA \\
\cline { 2 - 5 } Mineral & \multicolumn{3}{c}{$(\mathrm{mg} / \mathrm{kg})^{\mathrm{b}}$} & $\mathrm{Pr}>F^{\mathrm{c}}$ \\
\hline Antimony & $4.00 \pm 1.18$ & $5.74 \pm 1.36$ & $4.02 \pm 1.25$ & 0.611 \\
Boron & $189.0 \pm 6.5$ & $181.0 \pm 6.5$ & $196.8 \pm 6.5$ & 0.304 \\
Calcium & $466.5 \pm 85.0$ & $452.7 \pm 85.0$ & $524.7 \pm 85.0$ & 0.822 \\
Iron & $4.16 \pm 0.38$ & $4.67 \pm 0.38$ & $3.76 \pm 0.38$ & 0.247 \\
Magnesium & $918.6 \pm 13.2$ & $931.4 \pm 13.2$ & $957.9 \pm 13.2$ & 0.114 \\
Molybdenum & $0.43 \pm 0.30$ & $0.95 \pm 0.39$ & $0.52 \pm 0.35$ & 0.615 \\
Phosphorus & $7121 \pm 115$ & $7096 \pm 115$ & $7296 \pm 115$ & 0.415 \\
Potassium & $13,935 \pm 228$ & $14,035 \pm 228$ & $14,196 \pm 228$ & 0.719 \\
Sodium & $1604 \pm 53$ & $1476 \pm 53$ & $1581 \pm 53$ & 0.266 \\
Silicon & $54.0 \pm 6.2$ & $51.9 \pm 6.2$ & $57.3 \pm 6.2$ & 0.828 \\
Sulfur & $5845 \pm 98$ & $5816 \pm 98$ & $6030 \pm 98$ & 0.319 \\
Zinc & $24.0 \pm 0.8$ & $22.1 \pm 0.8$ & $23.4 \pm 0.8$ & 0.330
\end{tabular}

${ }^{\text {a }} \mathrm{N}=3$ replicate tanks.

b Dry matter basis.

ANOVA, $\mathrm{Pr}>\mathrm{F}$. LS means in the same row with different letters are different $(P \leq 0.05)$.

L, whereas in the Old-Hi treatment, where solids were not removed, mean TSS increased to a maximum of $1415 \mathrm{mg} / \mathrm{L}$. Catfish feed consumption and growth in BFT production system did not differ significantly between the Control treatment where maximum TSS concentration ranged from 1200 to $1410 \mathrm{mg} / \mathrm{L}$ and treatments where TSS concentrations were maintained at about $300 \mathrm{mg} / \mathrm{L}$ (Green et al., 2019a). However, the 5 to $11 \%$ reduction in feed consumption and $7 \%$ reduction in fish size in the Control treatment suggest that elevated TSS concentration adversely affects catfish performance. Growth of South American catfish (Rhamdia quelen) was not affected by $909 \mathrm{mg} / \mathrm{L}$ TSS concentration (Poli et al., 2015) whereas shrimp growth was better at TSS < 300 mg/L (Ray et al., 2010, 2011; Vinatea et al., 2010; Gaona et al., 2017). Thus, results from the present study and those of Green et al. (2019a) suggest that determination of an optimal upper limit for TSS concentration still is needed.

\subsection{Water quality dynamics}

Ammonia-nitrogen and $\mathrm{NO}_{2}-\mathrm{N}$ concentrations remained consistently low throughout the experiment in the Old water treatments because nitrification was fully functional from the beginning, whereas the typical lag in onset of nitrification (Luo et al., 2013; Green et al., 2019b) was observed in the New treatment. Un-ionized ammonia, estimated to comprise about $8 \%$ of the spike in $\mathrm{NH}_{4}-\mathrm{N}$ concentration in the New treatment during onset of nitrification at the prevailing water temperature and $\mathrm{pH}$, would be less than the reported LC50 of $2.4 \mathrm{mg} / \mathrm{L}$ un-ionized ammonia for channel catfish (Colt and Tchobanoglous, 1976). The addition of stock salt at the beginning of the study ensured enough chloride ions were present to mitigate any adverse effect of the spike in nitrite concentration that occurred during onset of nitrification (Tomasso et al., 1979, 1980). Excretion of feed nitrogen by fish in the present study was assumed similar among treatments because feed consumption and growth did not differ. The significantly higher mean $\mathrm{NO}_{3}-\mathrm{N}$ accumulation rates observed in the New and Old-Hi treatments compared to the Old-Lo treatments suggests nitrification in the latter treatment was impacted negatively. The overall significant difference in settling chamber water and solids discharge in Old-Lo treatment tanks compared to New treatment tanks does not explain fully the observed reduction in $\mathrm{NO}_{3}-\mathrm{N}$ accumulation rate. Examination on a monthly basis of $\mathrm{NO}_{3}-\mathrm{N}$ accumulation rate and settling chamber water and solids discharge provides additional insight. The $\mathrm{NO}_{3}-\mathrm{N}$ accumulation rate during June was 3.0 times higher, the mass of solids discharged was 3.2 times lower and the volume of water discharged was 2.1 times lower in the New treatment compared to the Old-Lo treatment. Although $\mathrm{NO}_{3}-\mathrm{N}$ accumulation rate between the New and Old-Lo treatments during August did not differ significantly, the $17 \%$ lower mean rate for the OldLo treatment may be explained by the significantly greater mass of solids and volume of water discharged in that treatment. These results suggest that the higher mass of solids removed from the Old-Lo treatment washed out nitrifying bacteria (Tchobanoglous et al., 2003; Ebeling et al., 2006) and dilution by the higher volume of make-up water acted alone or in concert to reduce nitrification in the Old-Lo treatment. Results from the present experiment are consistent with reported reductions in nitrification rate in response to TSS removal from 

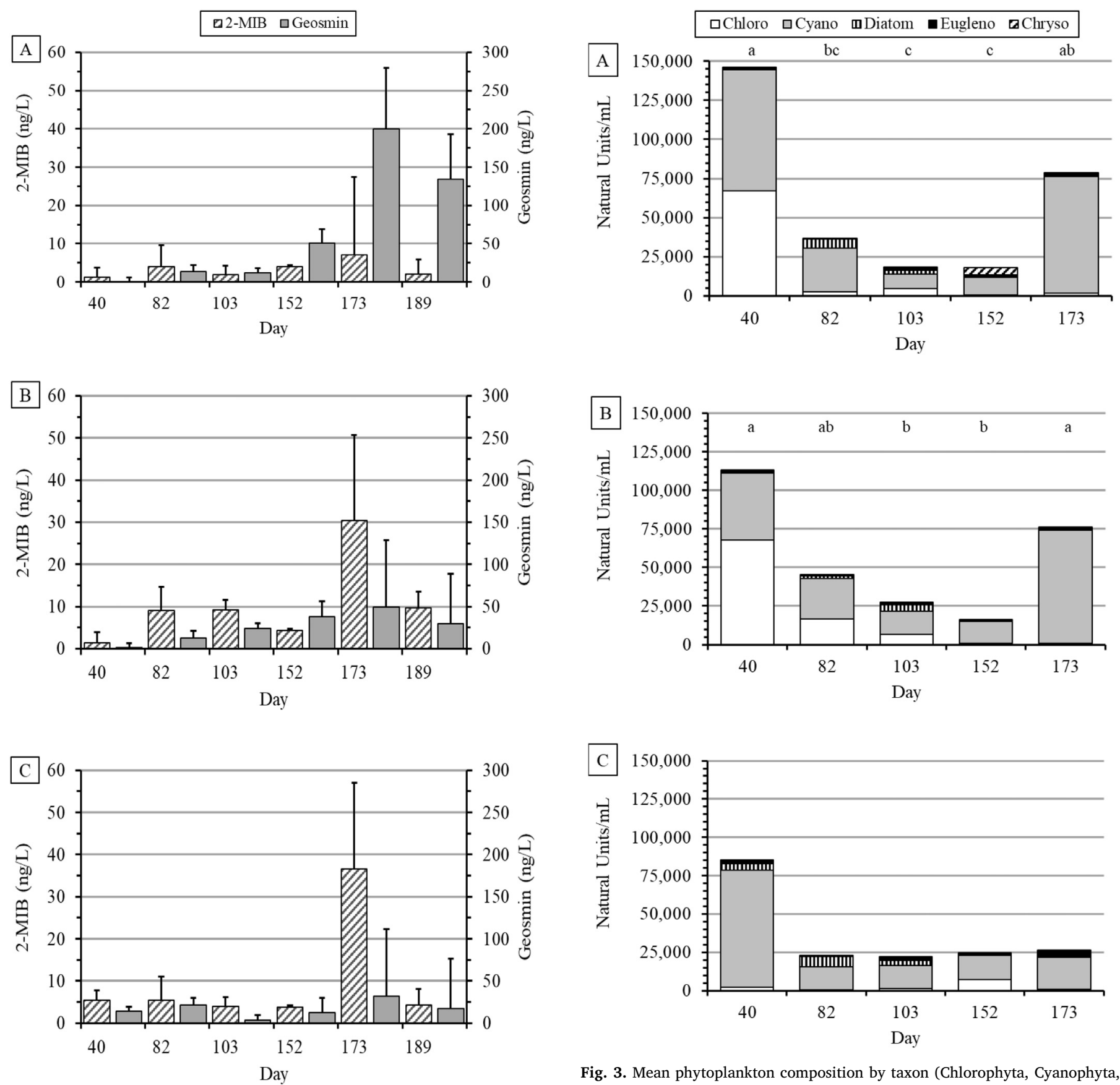

Fig. 2. Least squares mean concentrations ( $\pm S E$ ) over time in tank water of 2 methylisoborneol (MIB, left axis) and geosmin (right axis) in New (A), Old-Lo (B) and Old-Hi (C) treatment biofloc technology production system culture units stocked with channel catfish. Error bars are pooled SE. New treatment geosmin means with different letters are significantly different $(P>.05)$. $N=3$ replicate tanks.

shrimp BFT production system tanks (Ray et al., 2010, 2012; Schveitzer et al., 2013). Compared to new water, shrimp BFT production tanks seeded with 50 or $100 \%$ by volume of biofloc water from the previous production cycle had significantly lower mean $\mathrm{NH}_{4}-\mathrm{N}$ and $\mathrm{NO}_{2}-\mathrm{N}$ and significantly higher $\mathrm{NO}_{3}-\mathrm{N}$ concentrations (Krummenauer et al., 2014). Additional research on the optimum proportion of old biofloc water needed to establish nitrification rapidly in a new production cycle would be beneficial.

Catfish retain 30\% of feed phosphorus (Boyd, 1985) and in the BFT production system in HDPE-lined tanks excreted dietary phosphorus

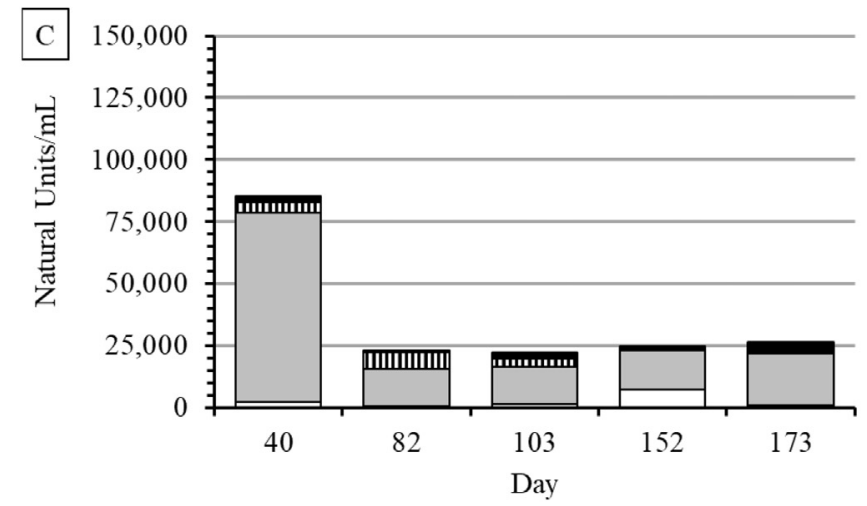

Fig. 3. Mean phytoplankton composition by taxon (Chlorophyta, Cyanophyta, Bacillariophyta, Euglenophyta, Chrysophyta) over time in New (A), Old-Lo (B) and Old-Hi (C) treatment biofloc technology production system culture units stocked with channel catfish. Letters above column within treatment indicates significant differences in total count among days. $N=3$ replicate tanks.

accumulates in contrast to earthen ponds where phosphorus is adsorbed by bottom soil (Masuda and Boyd, 1994). Significant differences among treatments in initial mean $\mathrm{PO}_{4}-\mathrm{P}$ concentration carried throughout the experiment despite similar total feed consumption among treatments. The absence of water discharge from the Old-Hi treatment and the significantly greater discharge of water and solids from the Old-Lo treatment compared to the New treatment likely explain the observed differences. Mean $\mathrm{PO}_{4}-\mathrm{P}$ concentration was significantly higher in shrimp BFT production system tanks seeded with 50 or $100 \%$ biofloc water from the previous production cycle compared to tanks that did not receive old biofloc water (Krummenauer et al., 2014).

Settling chamber operation maintained TSS concentrations within the 300 to $400 \mathrm{mg} / \mathrm{L}$ target range. The significantly higher initial TSS 
Table 7

Occurrence (natural units/mL) of phytoplankton in New, Old-Lo, and Old-Hi treatment biofloc technology production system culture tanks stocked with channel catfish.

\begin{tabular}{|c|c|c|c|c|c|c|}
\hline \multirow[b]{2}{*}{ Taxon } & \multicolumn{2}{|l|}{ New } & \multicolumn{2}{|l|}{ Old-Lo } & \multicolumn{2}{|l|}{ Old-Hi } \\
\hline & $\begin{array}{l}\text { No. } \\
\text { of dates (Tanks) }\end{array}$ & $\begin{array}{l}\text { Count } \\
\text { (natural units/mL) }\end{array}$ & $\begin{array}{l}\text { No. } \\
\text { of dates (Tanks) }\end{array}$ & $\begin{array}{l}\text { Count } \\
\text { (natural units/mL) }\end{array}$ & $\begin{array}{l}\text { No. } \\
\text { of dates (Tanks) }\end{array}$ & $\begin{array}{l}\text { Count } \\
\text { (natural units/mL) }\end{array}$ \\
\hline \multicolumn{7}{|l|}{ Cyanophyta } \\
\hline Jaaginema subtilissimum ${ }^{c}$ & $5(3)$ & $100-23,500^{d}$ & $4(3)$ & $400-56,200^{d}$ & $4(3)$ & $600-30,500^{d}$ \\
\hline Jaaginema angustissimum $^{c}$ & $5(3)$ & $1100-170,600^{\mathrm{d}}$ & $5(3)$ & $100-76,500^{\mathrm{d}}$ & $4(3)$ & $100-168,300^{\mathrm{d}}$ \\
\hline Polycystis spp. & $3(2)$ & $100-2300$ & $2(2)$ & $100-400$ & $2(2)$ & 100 \\
\hline Gomphospheria spp. & $2(2)$ & 100 & - & - & - & - \\
\hline Planktothrix agardhii ${ }^{c}$ & - & - & $1(1)$ & 400 & $1(2)$ & $200-500$ \\
\hline \multicolumn{7}{|l|}{ Chlorophyta } \\
\hline Scenedesmus spp. & $5(3)$ & $100-94,700^{\mathrm{d}}$ & $5(3)$ & $100-31,200^{\mathrm{e}}$ & $5(2)$ & $100-3000^{\mathrm{d}}$ \\
\hline Ankistrodesmus spp. & $5(3)$ & $100-8900^{\mathrm{e}}$ & $4(3)$ & $300-132,600^{\mathrm{d}}$ & $4(3)$ & $100-300$ \\
\hline Kirchneriella spp. & $4(3)$ & $100-4200$ & $3(1)$ & $200-500$ & $3(2)$ & $200-400$ \\
\hline Ulothrix spp. & $4(2)$ & $100-800$ & $5(3)$ & $100-19,200$ & $3(3)$ & $100-2300$ \\
\hline Closterium spp. & $3(2)$ & $100-600$ & $4(3)$ & $200-2000$ & $2(2)$ & $400-1200$ \\
\hline Pediastrum spp. & $3(3)$ & $100-2900$ & - & - & $2(2)$ & $100-300$ \\
\hline Schroederia spp. & $2(2)$ & $100-200$ & - & - & - & - \\
\hline Cosmarium spp. & $1(1)$ & 100 & - & - & $1(1)$ & 100 \\
\hline Crucigenia spp. & $1(1)$ & 100 & $1(1)$ & 100 & - & - \\
\hline Oocyctis spp. & $1(2)$ & $100-400$ & - & - & - & - \\
\hline Chlorella spp. & $1(2)$ & $100-300$ & $3(2)$ & $100-300$ & $3(3)$ & $100-700$ \\
\hline Coelastrum spp. & $1(1)$ & 200 & $2(1)$ & $100-200$ & $1(1)$ & 100 \\
\hline Golenkinia spp. & $1(1)$ & 100 & - & - & $1(2)$ & $1300-17,200^{d}$ \\
\hline Tetraedron spp. & $1(1)$ & 200 & - & - & - & - \\
\hline Tetraspora spp. & $1(1)$ & 100 & $1(1)$ & 100 & - & - \\
\hline Stigeoclonium spp. & - & - & $1(1)$ & 100 & - & - \\
\hline Schroederia spp. & - & - & $1(1)$ & 200 & $2(2)$ & 100 \\
\hline Unidentified spp. & $1(1)$ & 100 & $4(2)$ & $100-1600$ & - & - \\
\hline \multicolumn{7}{|l|}{ Bacillariophyceae } \\
\hline Pennate diatoms, unidentified & $4(3)$ & $100-8,300^{\mathrm{e}}$ & $4(3)$ & $200-5400^{e}$ & $4(3)$ & $100-15,300^{\mathrm{d}}$ \\
\hline Centric diatoms, unidentified & - & - & $1(1)$ & 100 & - & - \\
\hline \multicolumn{7}{|l|}{ Euglenophyta } \\
\hline Trachelomonas spp. & $5(3)$ & $200-3600$ & $5(3)$ & $100-3000$ & $5(3)$ & $100-9100^{\mathrm{e}}$ \\
\hline Euglena spp. & - & - & - & - & $2(2)$ & 100 \\
\hline \multicolumn{7}{|l|}{ Chrysophyceae } \\
\hline Unidentified spp. & $1(2)$ & $200-8,800^{\mathrm{e}}$ & $2(2)$ & 100 & $1(1)$ & 100 \\
\hline Mallamonas spp. & $1(1)$ & 100 & - & - & $1(1)$ & 100 \\
\hline
\end{tabular}

${ }^{\text {a }}$ Number of sampling dates in which the phytoplankton type was observed to be present in any of the tanks during any of the five sampling dates. There were 5

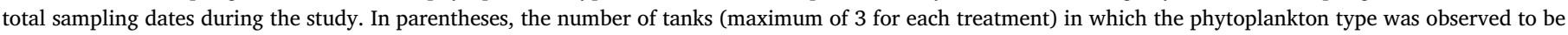
present on at least one sampling date during the study.

$\mathrm{b}$ Abundance as indicated by the count or range of counts of the phytoplankton type observed to be present in the tanks during the study.

c Jaaginema subtilissimum, Jaaginema angustissimum, and Planktothrix agardhii also known as Oscillatoria angustissima, Oscillatoria subtilissima or Lyngbya microscopica, and Oscillatoria agardhii, respectively.

d More than $50 \%$ of the total phytoplankton count for at least one sample.

e More than $25 \%$ of the total phytoplankton count for at least one sample. No superscript indicates never $>25 \%$ of the phytoplankton count.

concentration in the Old-Lo treatment compared to the New treatment meant that Old-Lo treatment solids removal began on day-21 compared to day-34 for the New treatment and higher solids discharge from the Old-Lo treatment during August and September explains the significant treatment difference in the quantity of solids and water discharged. Mean TSS concentration was significantly higher in shrimp BFT production system tanks seeded with $100 \%$ biofloc water from the previous production cycle compared to tanks seeded with 0 or $50 \%$ old biofloc water (Krummenauer et al., 2014).

\subsection{MIB and geosmin concentrations, and phytoplankton}

The low concentrations of MIB and geosmin measured in tank water samples on most sample dates except mid-October to early November were consistent with results reported for production of catfish (Schrader et al., 2011; Green et al., 2014) and hybrid tilapia (Green et al., 2019b) in the BFT system. The highest MIB concentrations in tank water occurred in one tank each in the Old-Lo and Old-Hi treatments in October and were 84 and $82 \mathrm{ng} / \mathrm{L}$, respectively, well below the typical MIB concentrations that can be present in pond water and result in off-flavor catfish from catfish production ponds in Alabama, Arkansas, Louisiana, and Mississippi (Schrader and Blevins, 1993; Schrader and Dennis, 2005; Zimba and Grimm, 2003). Similarly, the highest geosmin concentrations (472 and $334 \mathrm{ng} / \mathrm{L}$ ) were measured in one tank in the New treatment in October and November, respectively. In contrast, significantly higher geosmin concentrations of $>2000 \mathrm{ng} / \mathrm{L}$ can occur in the water of catfish production ponds (Schrader and Blevins, 1993; Zimba and Grimm, 2003). In another study conducted from July through September approximately 20 to $60 \%$ of commercial ponds in west Mississippi and 5 to $35 \%$ of ponds in the Mississippi-Alabama Blackland Prairie had MIB concentrations $>100 \mathrm{ng} / \mathrm{L}$, whereas geosmin concentrations $>100 \mathrm{ng} / \mathrm{L}$ were found in 0 to $15 \%$ and 10 to $25 \%$ of ponds, respectively (Schrader and Dennis, 2005). In general, the incidence and severity of these common off-flavor problems are less problematic in BFT systems compared to earthern catfish production ponds in the southeastern United States.

Phytoplankton communities present on the sample dates with the higher MIB and geosmin concentrations were dominated by cyanophytes in all treatments except for the first sample where chlorophytes co-dominated in the New and Old-Lo treatments. However, none of the 
cyanophyte genera and species found in the present study (Table 7) is known conclusively to produce MIB or geosmin. Jaaginema subtilissimum and Jaaginema angustissimum, Scenedesmus spp. and Ankistrodesmus spp., and pennate diatoms were the dominant types of cyanophytes, chlorophytes, and bacillariophytes, respectively, and also were the most dominant types present in previous channel catfish BFT studies (Schrader et al., 2011; Green et al., 2014). In contrast, the planktonic, bloom-forming species of Planktothrix peronata (MIB producer), Planktothrix agardhii, Raphidiopsis brookii, and Microcystis aeruginosa are common cyanophytes found during summer and early autumn months in catfish ponds (conventional and split ponds) in Mississippi and Alabama and are considered undesirable because they can produce toxins and/or off-flavor compounds (van der Ploeg and Tucker, 1993; Schrader and Dennis, 2005; Schrader et al., 2016). The water turbulence of the BFT system exposes phytoplankton to smallscale shear stress and prevents stratification of the water column, which favors the growth of the relatively larger cyanobacteria ( $P$. peronata, $P$. agardhii, R. brookii, and M. aeruginosa) in earthen ponds. Because these larger species of planktonic cyanobacteria can regulate their cell buoyancy by the collapse and reformation of intracellular gas vacuoles, they can outcompete other types of phytoplankton for light in turbid ponds with low rates of vertical mixing of the water and subsequent strong vertical gradients of light (Paerl and Tucker, 1995).

The predominant types of phytoplankton in the current study were smaller species of cyanophytes compared to those observed typically in catfish ponds and they were present usually in close association with the biofloc particles or embedded with the biofloc particles, which may have provided some protection from shear stress and some distribution within the water column from the mixing of the biofloc particles in the water of the BFT tanks. Phytoplankton abundance in the New and OldLo treatments was reduced in the day 82, 103, and 152 samples because of solids removal, but had increased in the day 173 samples in response to less frequent solids removal. The reduction in Old-Hi treatment phytoplankton abundance likely was in response to reduced light penetration as TSS concentration increased. Secchi disk visibility measured during previous channel catfish BFT studies ranged from 5 to $10 \mathrm{~cm}$ at TSS concentrations similar to those measured in the present study (B Green, unpublished data). Chlorophytes and cyanophytes were co-dominant in a brackish water shrimp BFT system and because cyanophytes were associated closely with biofloc particles their abundance decreased when solids were removed (Ray et al., 2010).

Whole-body lipid content coupled with water temperature and offflavor compound concentration are factors that affect the bioaccumulation of MIB and geosmin in catfish flesh (Howgate, 2004). In the present study, the absence of treatment differences in whole-body lipid content does not provide an explanation for the higher geosmin concentrations in the fillets of the New treatment catfish. High mean geosmin concentrations on day 173 and 189 samples suggests that bioaccumulation from prolonged exposure of New treatment fish to geosmin in the culture water may have affected fillet flavor status adversely. Trained catfish processing plant flavor testers can detect MIB and geosmin concentrations as low as 100 to $200 \mathrm{ng} / \mathrm{kg}$ and 250 to $500 \mathrm{ng} / \mathrm{kg}$, respectively (Grimm et al., 2004). Thus, fish from the New treatment likely would be classified as having an objectionable "earthy" off-flavor. In a previous study, catfish from BFT treatments in which solids were removed likely would have been deemed as off-flavor because of high fillet geosmin content whereas fish from the Control treatment were likely not off-flavor due to lower geosmin content (Green et al., 2019a). Typically, MIB-related off-flavor is more common than geosmin off-flavor in pond-raised catfish in the southeastern United States (van der Ploeg and Tucker, 1993), which is in contrast to many of our BFT studies so far.

The source of geosmin in tanks where solids were removed is unknown. None of the phytoplankton species found in water samples are known conclusively to produce MIB or geosmin. Concentrations of MIB and geosmin as high as 784 and $861 \mathrm{ng} / \mathrm{L}$, respectively, were measured in periphyton collected at the air-water interface of the BFT tank walls during harvest of hybrid tilapia in a recent BFT study and grazing of the periphyton by tilapia was postulated to be the source of fillet MIB and geosmin (Green et al., 2019b). Formulated feed and insects dominated pond-reared channel catfish stomach contents during summer months (Lilyestrom et al., 1987). Thus, in the absence of observed grazing behavior and given their feeding habits and being fed formulated ration to apparent satiation daily it is unlikely that channel catfish grazed on BFT tank wall periphyton. However, in the present experiment and in Green et al. (2019b), the light regime likely improved in tanks where TSS concentrations were maintained between 300 and $400 \mathrm{mg} / \mathrm{L}$ in comparison to tanks with high TSS concentration and may have allowed for periphyton to become established or more abundant (periphyton was not quantified in the present study). The role of periphyton as contributors to MIB and geosmin presence in aquatic systems is supported by the study of Watson and Ridal (2004) that found that increased water transparency in natural waterways allowed periphyton to proliferate and become a primary source of MIB and geosmin in overlying water.

\subsection{Mineral concentration of water, feed and fish}

Changes over the 181-d study in trace mineral concentrations in water were minimal or below method detection limits. All trace mineral concentrations were below National Recommended Aquatic Life Criteria (USEPA (U.S. Environmental Protection Agency), 1986, 2007, 2019). Major mineral concentrations in water increased during the study except for calcium, which decreased, and were in response to feed, sodium bicarbonate, and salt (sodium chloride) additions. The reduction in calcium concentration likely was caused by fish uptake (NRC (National Research Council), 2011). Accumulated mineral concentrations in initial Old water samples (Old-Lo and Old-Hi treatments) generally were higher than the initial water sample from the New treatment as would be expected. Treatment differences in final water sample mineral concentrations were related more to TSS removal than to new versus old water. Biofloc particles have a negative surface charge with high affinity for cations (Wilen et al., 2003; De Schryver et al., 2008), which suggests that solids and water discharge from the New and Old-Lo treatments contributed to the decreased mineral concentration in final water samples compare to the Old-Hi treatment. Additionally, because only dissolved mineral concentrations were measured in the present study, treatment differences in final water sample mineral concentrations may be related to their binding to biofloc particles. Similar changes in major and trace mineral concentrations occurred during saltwater BFT shrimp culture (Prangnell et al., 2016). To better understand the distribution of minerals between the dissolved and biofloc-bound fractions, biofloc mineral content should be quantified in future studies.

Whole-body mineral concentrations in harvested fish did not differ when one-year old water compared to new biofloc water was used despite treatment differences in some mineral concentrations in the culture water. Changes in the whole-body mineral concentrations between initial and harvested channel catfish likely were the result of normal growth. Formulated diet was the primary source of minerals for channel catfish and residual feed in the digestive tract of initial and harvested fish may have contributed to whole-body mineral concentrations. However, the amount of residual feed in the digestive tract likely was minimal because initial and harvested fish were not fed during the 4 to 5 days prior to sample collection. Apparent whole-body retention was low for most trace minerals and moderate to high for major minerals consumed as feed. Only apparent whole-body retention of calcium exceeded $100 \%$.

Sodium bicarbonate was added to tank water to maintain total alkalinity and $\mathrm{pH}$ required for good nitrification and contributed to the increased sodium concentration in final water samples. Fish obtain calcium, an important major mineral for fish growth and physiological 
function, from dietary intake and uptake from water (NRC (National Research Council), 2011). The significantly lower calcium concentration in the Old-Hi treatment final water sample suggests that use of BFT system water over multiple production cycles could result in calcium declining to a critical concentration. Periodic addition of calcium hydroxide for $\mathrm{pH}$ control in place of sodium bicarbonate would maintain or increase calcium concentration.

As was seen with whole-bodies, fillet mineral concentration of channel catfish grown in biofloc water from the previous year did not differ significantly compared to new biofloc water. Analytical levels of cadmium, copper, lead, and molybdenum, detected only in 9 to $51 \%$ of fillets analyzed, were variable ( $\mathrm{CV}=85$ to $101 \%$ ) and difficult to interpret. Fillet concentrations of boron, magnesium, potassium, and sulfur were higher than in whole bodies indicating their importance to muscle tissue. Mineral content of farm-raised channel catfish fillets from the Mississippi delta were shown not to vary seasonally (Nettleton et al., 1990; Robinson et al., 2001). On the other hand, channel catfish fillet mineral concentration from earthen ponds located in three different geographic/geochemical areas in Alabama and Mississippi did differ significantly among geographic locations (Li et al., 2013). Additionally, results from another study reported by Li et al. (2013) showed that channel catfish fed diets that contained significantly different mineral concentrations did not result in significant differences in fillet mineral concentration except for sodium. Results reported by Li et al. (2013) suggest that culture water mineral concentrations influence fillet mineral content more than formulated feed. In contrast, results from the present study suggest that differences in water mineral concentrations among treatments did not affect whole-body or fillet mineral concentrations. However, Li et al. (2013) did not evaluate year to year variation in fillet mineral content within location.

Macro- and trace-minerals are important components of a nutritionally complete human diet. Because no significant treatment differences of fillet mineral concentration were detected in the present study, grand means of selected minerals in fillet tissue (as is) were calculated and compared with other published data (Table 8). Overall, mineral concentrations in a 100-g portion (as is) of channel catfish fillet meat were comparable to other published values. Additionally, mineral concentrations in a 100-g portion of channel catfish fillet were within the recommended dietary intake and less than the tolerable upper intake levels (Institute of Medicine, 2001, 2011).

\subsection{Summary}

In summary, one-year old water from a channel catfish BFT production system can be used for a second year of BFT production with no adverse effect on channel catfish production responses. One advantage to re-use of BFT system water is the absence of $\mathrm{NH}_{4}-\mathrm{N}$ and $\mathrm{NO}_{2}-\mathrm{N}$ concentration spikes typical of BFT start-up. Although a maximum TSS concentration of $1415 \mathrm{mg} / \mathrm{L}$ in the Old-Hi treatment did not affect daily feed consumption, variable results from other studies suggest that an optimal upper TSS concentration limit remains to be determined. On the other hand, accumulation of TSS in the channel catfish BFT system, i.e., no TSS removal, appears to favor a lower occurrence of catfish that would be classified as having "musty" or "earthy" off-flavors. Furthermore, results suggest that TSS removal may reduce nitrification because discharging solids washes nitrifying bacteria out of the system. Macro- and trace-minerals accumulate in water during the culture cycle, and treatment differences were related more to solids removal than to new versus old BFT water. Whole-body and fillet mineral concentrations did not differ when channel catfish were grown in one-year old or new BFT system water. Further research is needed to determine the number of production cycles for which biofloc water can be re-used and the best strategy and limits for re-use of biofloc water over multiple production cycles.

\section{Funding}

This research did not receive any specific grant from funding agencies in the public, commercial, or not-for-profit sectors.

\section{Declaration of Competing Interest}

The authors declare that they have no known competing financial interests or personal relationships that could have appeared to influence the work reported in this paper.

\section{Acknowledgements}

We thank the following USDA-ARS personnel for their substantial efforts toward daily animal husbandry, fish sampling and harvest, and laboratory analyses: Greg O'Neal, Paxton Harper, Rebecca Roberts, Dewayne Harries, Phaedra Page, and William Scheiderer.

This study was funded by USDA-ARS under project 6225-31630-

Table 8

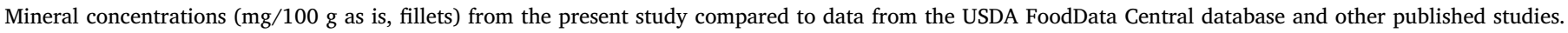

\begin{tabular}{|c|c|c|c|c|c|c|}
\hline \multirow[b]{2}{*}{ Mineral } & \multicolumn{6}{|c|}{$\mathrm{mg} / 100 \mathrm{~g}$, as is } \\
\hline & $\begin{array}{l}\text { Current } \\
\text { Study }\end{array}$ & $\begin{array}{l}\text { USDA } \\
\text { FoodData } \\
\text { Central (USDA 2019) }\end{array}$ & Mustafa and Medeiros (1985) & Nettleton et al. (1990) & Clement and Lovell (1994) & Robinson et al. (2001) \\
\hline Aluminum & $<0.100$ & - & - & - & 0.07 & - \\
\hline Barium & $<0.100$ & - & - & - & 0.04 & - \\
\hline Boron & 6.01 & - & - & - & 0.07 & - \\
\hline Cadmium & $<0.100$ & - & - & $<0.004$ & - & - \\
\hline Calcium & 14.0 & 8 & 10 & 7.1 & 15.30 & 9 \\
\hline Cobalt & $<0.100$ & - & - & - & $<0.01$ & $<0.11$ \\
\hline Copper & 0.026 & 0.032 & 0.23 & $<0.06$ & 0.04 & $<0.03$ \\
\hline Iron & 0.122 & 0.23 & 1.0 & 0.34 & 1.66 & 0.50 \\
\hline Lead & 0.039 & - & - & $<0.005$ & $<0.01$ & \\
\hline Magnesium & 27.2 & 19 & 22 & 23 & 25.96 & 22 \\
\hline Manganese & $<0.100$ & 0.015 & - & $<0.03$ & 0.07 & $<0.11$ \\
\hline Molybdenum & 0.016 & - & - & - & 0.01 & \\
\hline Phosphorus & 208.5 & 204 & 221 & 184 & 184 & 180 \\
\hline Potassium & 408.7 & 302 & 250 & 315 & 348 & 354 \\
\hline Sodium & 45.2 & 98 & 98 & 33 & 34.46 & 40 \\
\hline Silicon & 1.581 & - & - & - & 0.97 & \\
\hline Zinc & 0.673 & 0.48 & 1.1 & 0.57 & 0.78 & 0.59 \\
\hline
\end{tabular}


005-D. USDA is an equal opportunity provider and employer. Mention of trade names or commercial products in this article is solely for providing specific information and does not imply recommendation or endorsement by the U.S. Department of Agriculture.

\section{References}

AOAC (Association of Official Analytical Chemists), 2006. AOAC Official Methods, 18th ed. Association of Official Analytical Chemists, Incorporated, Arlington.

Boyd, C.E., 1985. Chemical budgets for channel catfish ponds. Trans. Am. Fish. Soc 114, 291-298.

Clement, S., Lovell, R.T., 1994. Comparison of processing yield and nutrient composition of cultured Nile tilapia (Oreochromis niloticus) and channel catfish (Ictalurus punctatus). Aquaculture 119, 299-310.

Colt, J., 2006. Water quality requirements for reuse systems. Aquac. Eng. 34, 143-156. Colt, J., Tchobanoglous, G., 1976. Evaluation of the short-term toxicity of nitrogenous compounds to channel catfish, Ictalurus punctatus. Aquaculture 8, 209-224.

De Schryver, P., Crab, R., Defoirdt, T., Boon, N., Verstraete, W., 2008. The basics of bioflocs technology: the added value for aquaculture. Aquaculture 277, 125-137.

Ebeling, J.M., Timmons, M.B., Bisogni, J.J., 2006. Engineering analysis of the stoichiometry of photoautotrophic, autotrophic, and heterotrophic removal of ammonia-nitrogen in aquaculture systems. Aquac. Eng. 257, 346-358.

Gaona, C.A.P., Souza de Almeida, M., Viau, V., Poersch, L.H., Wasielesky Jr., W., 2017 Effect of different total suspended solids levels on a Litopenaeus vannamei (Boone, 1931) BFT culture system during biofloc formation. Aquac. Res. 48, 1070-1079.

Gbur, E.E., Stroup, W.W., McCarter, K.S., Durham, S., Young, L.J., Christman, M., West, M., Kramer, M., 2012. Analysis of Generalized Linear Mixed Models in the Agricultural and Natural Resources Sciences. American Society of Agronomy, Soil Science Society of America, Crop Science Society of America, Incorporated, Madison. Green, B.W., 2010. Effect of channel catfish stocking rate on yield and water quality in an intensive, mixed suspended-growth production system. N. Am. J. Aquac. 72, 97-106.

Green, B.W., 2015. Performance of a temperate-zone channel catfish biofloc technology production system during winter. Aquac. Eng. 64, 60-67.

Green, B.W., Schrader, K.K., Perschbacher, P., 2014. Effect of stocking biomass on solids, phytoplankton communities, common off-flavors, and production parameters in channel catfish biofloc technology production system. Aquac. Res. 45, 1442-1458.

Green, B.W., Schrader, K.K., McEntire, M.E., 2019a. Effect of solids removal on water quality and channel catfish production in a biofloc technology production system. J. Appl. Aquac. 31, 1-16.

Green, B.W., Rawles, S.D., Schrader, K.K., Gaylord, T.G., McEntire, M.E., 2019b. Effects of dietary protein content on hybrid tilapia (Oreochromis aureus $\mathrm{x} O$. niloticus) performance, common microbial off-flavor compounds, and water quality dynamics in an outdoor biofloc technology production system. Aquaculture 503, 571-582.

Grimm, C.C., Lloyd, S., Zimba, P.V., 2004. Instrumental versus sensory detection of offflavors in farm-raised channel catfish. Aquaculture 236, 309-319.

Howgate, P., 2004. Tainting of farmed fish by geosmin and 2-methyl-iso-borneol: a review of sensory aspects and of uptake/depuration. Aquaculture 234, 155-181.

Huey, D.W., Simco, B.A., Criswell, D.W., 1980. Nitrite-induced methemoglobin formation in channel catfish. Trans. Am. Fish. Soc. 109, 558-562.

Institute of Medicine, 2001. Dietary Reference Intakes for Vitamin A, Vitamin K, Arsenic, Boron, Chromium, Copper, Iodine, Iron, Manganese, Molybdenum, Nickel, Silicon, Vanadium, and Zinc. Institute of Medicine of the National Academies, Washington, DC. https://www.ncbi.nlm.nih.gov/books/NBK222322/ (accessed 22 September 2019).

Institute of Medicine, 2011. Dietary Reference Intakes for Calcium and Vitamin D, Summary Tables. Institute of Medicine of the National Academies, Washington, DC. https://www.ncbi.nlm.nih.gov/books/NBK56068/ (accessed 22 September 2019).

Krummenauer, D., Samocha, T., Poersch, L., Lara, G., Wasielesky Jr., W., 2014. The reuse of water on the culture of Pacific white shrimp, Litopenaeus vannamei, in BFT system. J. World Aquacult. Soc. 45, 3-14.

Li, L., Boyd, C.E., Odom, J., Dong, S., 2013. Identification of Ictalurid catfish fillets to rearing location using elemental profiling. J. World Aquacult. Soc. 44, 405-414.

Li, L., Ren, W., Liu, C., Dong, S., Zhu, Y., 2018. Comparing trace element concentrations in muscle tissue of marbled eel Anguilla marmorata reared in three different aquaculture systems. Aquacult. Environ. Interact. 10, 13-20.

Lilyestrom, C.G., Romaire, R.P., Aharon, P., 1987. Diet and food assimilation by channel catfish and Malaysian prawns in polyculture as determined by stomach content analysis and stable carbon isotope ratios. J. World Aquacult. Soc. 18, 278-288.

Loyless, J.C., Malone, R.F., 1997. A sodium bicarbonate dosing methodology for $\mathrm{pH}$ management in freshwater-recirculating aquaculture systems. Prog. Fish-Cult. 59, 198-205.

Luo, G.-Z., Avnimelech, Y., Pan, Y.-F., Tan, H.-X., 2013. Inorganic nitrogen dynamics in sequencing batch reactors using biofloc technology to treat aquaculture sludge. Aquac. Eng. 52, 73-79.

Masuda, K., Boyd, C.E., 1994. Phosphorus fractions in soil and water of aquaculture ponds built on clayey ultisols at Auburn, Alabama. J. World Aquacult. Soc. 25, 379-395.

Mustafa, F.A., Medeiros, D.M., 1985. Proximate composition, mineral content, and fatty acids of catfish (Ictalurus punctatus, Rafinesque) for different seasons and cooking methods. J. Food Sci. 50, 585-588.

Nettleton, J.A., Allen Jr., W.H., Klatt, L.V., Ratnayake, W.M.N., Ackman, R.G., 1990. Nutrients and chemical residue in one- to two-pound Mississippi farm-raised channel catfish (Ictalurus punctatus). J. Food Sci. 55, 954-958.

NRC (National Research Council), 2011. Nutrient Requirements of Fish and Shrimp. National Research Council of the National Academies, Washington.
Paerl, H.W., Tucker, C.S., 1995. Ecology of blue-green algae in aquaculture ponds. J. World Aquacult. Soc. 26, 109-131.

van der Ploeg, M., Tucker, C.S., 1993. Seasonal trends in flavor quality of channel catfish, Ictalurus punctatus, from commercial ponds in Mississippi. J. Appl. Aquac. 3, $121-140$.

Poli, M.A., Schveitzer, R., Nuñer, A.P., 2015. The use of biofloc technology in a south American catfish (Rhamdia quelen) hatchery: effect of suspended solids on the performance of larvae. Aquac. Eng. 66, 17-21.

Prangnell, D.I., Castro, L.F., Ali, A.S., Browdy, C.L., Zimba, P.V., Laramore, S.E., Samocha, T.M., 2016. Some limiting factors in superintensive production of juvenile Pacific white shrimp, Litopenaeus vannamei, in no-water-exchange, biofloc-dominated systems. J. World Aquacult. Soc. 47, 396-413.

Rawles, S.D., Green, B.W., McEntire, M.E., Gaylord, T.G., Barrows, F.T., 2018. Reducing dietary protein in pond production on hybrid striped bass (Morone chrysops $\times M$. saxatillis): effects on fish performance and water quality dynamics. Aquaculture 490, 217-227.

Ray, A.J., Lewis, B.L., Browdy, C.L., Leffler, J.W., 2010. Suspended solids removal to improve shrimp (Litopenaeus vannamei) production and an evaluation of a plant-based feed in minimal-exchange, superintensive culture systems. Aquaculture 299, 89-98.

Ray, A.J., Dillon, K.M., Lotz, J.M., 2011. Water quality dynamics and shrimp (Litopenaeu. vannamei) production in intensive, mesohaline culture systems with two levels of biofloc management. Aquac. Eng. 45, 127-136.

Ray, A.J., Seaborn, G., Vinatea, L., Browdy, C.L., Leffler, J.W., 2012. Effects of biofloc reduction on microbial dynamics in minimal-exchange, superintensive shrimp, Litopenaeus vannamei, culture systems. J. World Aquacult. Soc. 43, 790-801.

Robinson, E.H., Li, M.H., Oberle, D.F., 2001. Nutrient Characteristics of Pond-Raised Channel Catfish. Research Report 22, Mississippi Agricultural \& Forestry Experiment Station. Mississippi State University. http://fisheries.tamu.edu/files/2013/09/ Nutrient-Characteristics-of-Pond-Raised-Channel-Catfish1.pdf (accessed 20 September 2019).

Schrader, K.K., Blevins, W.T., 1993. Geosmin-producing species of Streptomyces and Lyngbya from aquaculture ponds. Can. J. Microbiol. 39, 834-840.

Schrader, K.K., Dennis, M.E., 2005. Cyanobacteria and earthy/musty compounds found in commercial catfish (Ictalurus punctatus) ponds in the Mississippi Delta and Mississippi-Alabama Blackland prairie. Water Res. 39, 2807-2814.

Schrader, K.K., Green, B.W., Perschbacher, P.W., 2011. Development of phytoplankton communities and common off-flavors in a biofloc technology system used for the culture of channel catfish (Ictalurus punctatus). Aquac. Eng. 45, 118-126.

Schrader, K.K., Tucker, C.S., Brown, T.W., Torrans, E.L., Whitis, G.N., 2016. Comparison of phytoplankton communities in catfish split-pond aquaculture systems with conventional ponds. N. Am. J. Aquac. 78, 384-395.

Schveitzer, R., Arantes, R., Costodio, P.F.S., Do Espirito Santo, C.M., Arana, L.V., Seiffert, W.Q., Andreatta, E.R., 2013. Effect of different biofloc levels on microbial activity, water quality and performance of Litopenaeus vannamei in a tank system operated with no water exchange. Aquac. Eng. 56, 59-70.

Schwedler, T.E., Tucker, C.S., 1983. Empirical relationship between percent methemoglobin in channel catfish and dissolved nitrite and chloride in ponds. Trans. Am. Fish. Soc. 112, 117-119.

Sokal, R.R., Rohlf, F.J., 1995. Biometry: The Principles and Practice of Statistics in Biological Research, 3rd ed. W.H. Freeman and Company, New York.

Tchobanoglous, G., Burton, F.L., Stensel, H.D., 2003. Wastewater Engineering: Treatment and Reuse - Metcalf \& Eddy, Inc, 4th ed. McGraw-Hill, New York.

Tomasso, J.R., Simco, B.A., Davis, K.B., 1979. Chloride inhibition of nitrite-induced methemoglobinemia in channel catfish (Ictalurus punctatus). J. Fish. Res. Board Can. $36,1141-1144$.

Tomasso, J.R., Wright, M.I., Simco, B.A., Davis, K.B., 1980. Inhibition of nitrite-induced toxicity in channel catfish by calcium chloride and sodium chloride. Prog. Fish Cult. 42, 144-146.

USDA (U.S. Department of Agriculture), 2019. FoodData Central. U.S. Department of Agriculture, Washington, DC. https://fdc.nal.usda.gov/fdc-app.html\#/food-details/ 175165/nutrients (accessed 22 September 2019).

USEPA (U.S. Environmental Protection Agency), 1986. Water Quality Criteria for Water U.S. Environmental Protection Agency, Washington, DC. https://www.epa.gov/ sites/production/files/2018-10/documents/quality-criteria-water-1986.pdf (accessed 17 September 2019).

USEPA (U.S. Environmental Protection Agency), 2007. Aquatic Life Ambient Freshwater Quality Criteria. Copper. U.S. Environmental Protection Agency, Washington, DC. https://www.epa.gov/wqc/aquatic-life-ambient-freshwater-quality-criteria-copper2007-revision (accessed 17 September 2019).

USEPA (U.S. Environmental Protection Agency), 2019. National Recommended Water Quality Criteria - Aquatic Life Criteria Table. U.S. Environmental Protection Agency, Washington, DC. https://www.epa.gov/wqc/national-recommended-water-qualitycriteria-aquatic-life-criteria-table (accessed 17 September 2019).

Vinatea, L., Galvez, A.O., Browdy, C.L., Stokes, A., Venero, J., Haveman, J., Lewis, B.L., Lawson, A., Shuler, A., Leffler, J.W., 2010. Photosynthesis, water respiration and growth performance of Litopenaeus vannamei in a super-intensive raceway culture with zero water exchange: interaction of water quality variables. Aquac. Eng. 42, $17-24$.

Watson, S.B., Ridal, J., 2004. Periphyton: a primary source of widespread and severe taste and odor. Water Sci. Technol. 49, 33-39.

Wilen, B.-M., Jin, B., Lant, P., 2003. The influence of key chemical constituents in activated sludge on surface and flocculating properties. Water Res. 37, 2127-2139.

Zimba, P.V., Grimm, C.C., 2003. A synoptic survey of musty/muddy odor metabolites and microcystin toxin occurrence and concentration in southeastern USA channel catfish (Ictalurus punctatus Ralfinesque) production ponds. Aquaculture 218, 81-87. 